\title{
PERLINDUNGAN HUKUM TERHADAP KORBAN PENGANIAYAAN DALAM PENANGANAN TINDAK PIDANA DI INDONESIA
}

\author{
Oleh : \\ Hasmiah Hamid
}

Perlindungan hukum terhadap hak-hak korban penganiayaan yang dirasakan saat ini masih minim padahal masalah keadilan tidak hanya berlaku terhadap pelaku penganiayaan saja akan tetapi juga korban penganiayaan. Hal ini terjadi karena eksistensi dan posisi hukum korban tindak pidana dalam sistem peradilan pidana hanya sebagai saksi (pelapor dan korban), dimana korban tidak termasuk dalam bagian dari unsur yang terlibat dalam sistem peradilan pidana sebagaimana terdakwa, polisi dan jaksa. Melalui penelitian ini, diharapkan agar perlindungan hakhak korban penganiayaan kedepannya dapat segera diambil langkah-langkah antara lain dalam hukum acara pidana nasional memuat ketentuan yang jelas, tegas, dan berimbang mengenai perlindungan terhadap hak-hak korban penganiayaan dan demi tercapainya tujuan penegakan hukum maka kiranya perlu dilakukan upaya pembaharuan hukum pidana atau upaya melakukan peninjauan dan pembentukan kembali (reorientasi dan reformasi) ketentuan hukum acara pidana mengenai perlindungan terhadap korban penganiayaan.

\section{KATA KUNCI : \\ Perlindungan Hukum, Korban Penganiayaan dan Hak-hak korban}

\section{A. PENDAhUluan}

\section{Latar Belakang}

Negara Indonesia adalah negara hukum (rechtsstaat) dimana hukum pada dasarnya bertujuan untuk mencapai kedamaian hidup bersama, yang merupakan keserasian antara ketertiban dan ketentraman. ${ }^{1}$

Hal ini tersirat dalam pembukaan Undang-Undang Dasar 1945 alinea IV dimana disebutkan bahwa tujuan negara Indonesia yang melindungi segenap bangsa Indonesia dan seluruh tumpah darah Indonesia, memajukan kesejahteraan umum, mencerdaskan kehidupan bangsa, dan ikut melaksanakan ketertiban dunia. Dalam hal Indonesia sebagai negara hukum tercermin dalam pasal 1 ayat 3 UndangUndang Dasar Negara RI. Tahun 1945, bahwa "Negara Indonesia adalah negara hukum" serta dalam Pasal 28 G Undang-Undang Dasar 1945 menegaskan mengenai perlindungan hak asasi manusia.

Indonesia sebagai negara hukum memberikan perlindungan bagi warga negaranya dengan menyediakan lembaga yang mampu memberikan keadilan dalam bentuk peradilan yang bebas dan tidak memihak. Hal ini didasari pandangan bahwa setiap manusia sejak kelahirannya menyandang hakhak dan kewajiban yang bersifat bebas dan asasi, negara serta penyelenggaraan kekuasan suatu negara tidak boleh mengurangi arti atau makna kebebasan dan hak-hak asasi kemanusian itu.

Salah satu bentuk perlindungan terhadap masyarakat yang harus dilakukan oleh negara adalah memberikan perlindungan hukum melalui proses peradilan apabila terjadi tindak pidana atau disebut sebagai sistem peradilan pidana (criminal justice sistem). Salah satu pihak yang sangat membutuhkan perlindungan dalam suatu tindak pidana adalah korban tindak pidana. Peran penting korban untuk diberikan perhatian dan perlindungan berangkat dari pemikiran bahwa korban merupakan pihak yang dirugikan dalam terjadinya suatu kejahatan sehingga harus mendapat perhatian dan pelayanan dalam rangka memberikan perlindungan terhadap kepentingannya.

\footnotetext{
${ }^{1}$ Soejono Soekanto, Sosiologi Suatu Pengantar, PT. Raja Grafindo Persada, Jakarta, 2007, hal 179.
} 
Korban tindak pidana lemah dalam perlindungan hukum, sejak korban melaporkan terjadi tindak pidana dan menunjukkan siapa pelaku tindak pidana dan atau dengan menyerahkan barang bukti dan ditemukan ditempat kejadian perkara termasuk penderitaan baik fisik maupun non fisik serta kerugian materil dan kerugian non materil kepada aparat penegak hukum (POLRI). Dengan korban telah melaporkan hal tersebut diatas, maka korban tidak memiliki akses untuk mendapatkan foto copy arsip laporan polisi. Berita acara pemeriksaan korban/pelapor dan saksi, surat perintah penyidikan, surat perintah penuntutan, berkas perkara yang diserahkan kepada jaksa penuntut umum, pelimpahan tersangka dan barang bukti kepada jaksa penuntut umum, pelimpahan surat dakwaan kepada pengadilan negeri, dakwaan dan tuntutan pidana serta putusan pengadilan negeri apalagi untuk mendapatkan kompensasi atas penderitaan dan kerugian yang diderita oleh pihak korban sampai mempunyai kekuatan hukum tetap. ${ }^{2}$

Keberadaan suatu peradilan yang adil (fair trial) merupakan tuntutan dan prinsip dasar hak asasi manusia yang universal dan ciri negara demokratis. Kelancaran dan keberhasilan suatu proses peradilan khususnya peradilan pidana, akan tergantung pada alat bukti yang berhasil dimunculkan di pengadilan. Salah satu alat bukti yang menentukan ialah keterangan saksi dan korban.

Dalam proses persidangan terhadap sebuah perkara pidana, korban menempati posisi yang penting untuk dapat mengungkap peritiwa pidana tersebut namun selama ini pembuat undang-undang dan para penegak hukum umumnya hanya tertuju pada pelaku tindak pidana dalam hal bagaimana menemukan cara atau metode penjatuhan sanksi yang lebih tegas dan adil agar pelaku kejahatan merasa jera atau mencegah orang untuk melakukan kejahatan. Lebih lanjut disebutkan bahwa fokus perhatian pada korban kejahatan sering menjadi terabaikan karena selama ini keberadaan korban dalam proses peradilan pidana khususnya pada tahap penyidikan nampaknya kurang mendapat perhatian dan kurang mendapat perlindungan hukum. Sebagai seorang korban kejahatan, ia mempunyai hak seperti manusia lainnya, sebagaimana dijamin dalam konvensi-konvensi hak asasi manusia dan secara legal dilindungi oleh perjanjian tersebut. ${ }^{3}$

Ketentuan-ketentuan mengenai perlindungan terhadap korban kejahatan di dalam Kitab Undang-undang Hukum Acara Pidana lebih dominan memberikan pengaturan mengenai ganti rugi sebagaimana diatur dalam Pasal 98 sampai dengan 101 KUHAP. Penggabungan perkara perdata dan pidana memang diatur dalam pasal 98 KUHAP namun penggabungan perkara tersebut jarang terjadi dimana korban lebih memilih melakukan tuntutan ganti kerugian setelah perkara pidananya telah memperoleh kekuatan hukum yang tetap.

Perlindungan terhadap korban pada dasarnya telah diatur dalam beberapa peraturan perundang-undangan di Indonesia sebagai pengejawantahan hak-hak asasi manusia dalam konstitusi dan hak-hak korban dalam KUHAP. Peraturan perundang-undang yang dimaksud adalah UndangUndang Republik Indonesia No. 13 Tahun 2006 tentang Perlindungan Saksi dan Korban, Peraturan Pemerintah No. 27 tahun 1983. Pelaksanaan Kitab Undang-undang Hukum Acara Pidana, mengarahkan negara melalui Depertemen Keuangan dibebani tanggung jawab untuk menyelesaikan pembayaran ganti kerugian yang dikabulkan pengadilan. Dalam UU No. 13 tahun 2006, restitusi dapat diberikan kepada semua korban tindak pidana yang terjadi dan tidak terbatas pada korban pelanggaran HAM yang berat sebagaimana hak atas kompensasi yang diatur dalam UU Pengadilan Hak Asasi Manusia.

Sistem peradilan pidana mengutamakan perlindungan hak-hak asasi manusia, namun apabila ketentuan-ketentuan mengenai hal itu diperhatikan secara lebih mendalam, ternyata hanya hak-hak tersangka/terdakwa yang banyak ditonjolkan sedangkan hak-hak dari korban tindak pidana sangat sedikit diatur.

\footnotetext{
2 Abdussalam. Victimologi. PTIK Press, Jakarta 2010. HIm. 36

3 Ansori. 2011. Perlindungan Hukum Terhadap Korban Perkosaan Dalam Peradilan Pidana di Indonesia. Disertasi. Universitas Brawijaya : Malang. HIm. 1
} 
Pelaku kejahatan sejak awal telah dilingkupi oleh berbagai bentuk perlindungan hukum, seperti memperoleh bantuan hukum, memperoleh perlakuan yang baik dijauhkan dari penyiksaan, diberitahukan tentang kejahatan yang dituduhkan kepadanya, diberi hak untuk mengajukan ganti kerugian, dan rehabilitasi apabila ditangkap, ditahan, atau diadili tanpa alasan berdasarkan undang-undang. ${ }^{4}$

Perlindungan dan bantuan bagi korban tindak pidana adalah hal mendesak dan penting untuk segera diimplementasikan. Minimnya pemberian perlindungan dan bantuan terhadap korban tindak pidana, justru memberi sumbangsih besar bagi merosotnya kualitas penegakan hukum dalam suatu negara. Dalam proses persidangan terhadap suatu perkara pidana, korban menempati posisi yang penting untuk dapat terungkapnya suatu peristiwa pidana, salah satu korban yang dimaksud adalah korban penganiayaan. Hal ini dapat dilihat dengan adanya beberapa kasus penganiayaan yang terjadi di Kota Tidore Kepulauan yang mengakibatkan korban luka berat dan belum mendapatkan perlindungan yang memadai terutama terhadap apa yang menjadi hak korban itu sendiri.

Salah satu kasus penganiayaan yang terjadi pada tahun 2014 di Kota Tidore Kepulauan, dimana seorang korban penganiayaan bernama Rahman Djuber mengalami luka berat dan pelakunya diproses mulai dari kepolisian sampai di pengadilan dan pelaku dijatuhi pidana dan putusan tersebut telah mempunyai kekuatan hukum yang tetap, namun korban tidak mendapat perlindungan sebagaimana yang dimaksud dalam Undang-Undang Nomor 13 Tahun 2006 yaitu mendapatkan restitusi atau kompensasi dan rehabilitasi.

Pemberian kompensasi dan restitusi diatur secara rinci dalam Peraturan Pemerintah Nomor 2 tahun 2002 tentang kompensasi, restitusi dan rehabilitasi terhadap korban pelanggaran HAM berat; dan Peraturan Pemerintah Nomor 44 Tahun 2008 tentang pemberian kompensasi, restitusi, bantuan. Menurut ketentuan Pasal 8 Undang-Undang Perlindungan Saksi dan Korban menentukan bahwa perlindungan dan hak korban diberikan sejak tahap penyelidikan dimulai dan berakhir sesuai dengan ketentuan sebagaimana diatur dalam Undang - Undang.

Korban penganiayaan yang pada dasarnya merupakan pihak yang paling menderita dalam suatu tindak pidana, karena tidak memperoleh perlindungan sesuai yang diberikan oleh undang-undang kepada pelaku penganiayaan, Korban dikategorikan sebagai alat bukti yang memberi keterangan yaitu hanya sebagai saksi, sehingga kecil kemungkinan bagi korban untuk memperoleh keleluasaan dalam memperjuangkan haknya. Korban tidak diberi kewenangan dan tidak terlibat secara aktif dalam proses penyidikan dan persidangan, sehingga ia kehilangan kesempatan untuk memperjuangkan hak-hak dan memulihkan keadaanya akibat suatu penganiayaan.

Perhatian terhadap kepentingan korban dapat dipandang sebagai unsur penting dalam rangka upaya penegakan hukum secara benar dan tepat, dalam hal ini fokus utama adalah pada perlakuan yang benar atau setepatnya terhadap pihak korban terutama ketentuan tentang penyediaan dan pemberian informasi yang dapat dimengerti kepada pihak korban, yang menderita kerugian akibat suatu tindak pidana oleh polisi maupun jaksa. ${ }^{5}$

Bertolak dari uraian diatas menggambarkan adanya kecenderungan tidak dilindunginya hakhak korban hanya tertuju kepada pelaku penganiayaan padahal masalah keadilan dan penghormatan masalah hak asasi manusia tidak hanya berlaku terhadap pelaku saja tetapi juga terhadap korban. Oleh karena itu penulis tertarik untuk melakukan penelitian dengan judul "Perlindungan hukum terhadap korban penganiayaan dalam penanganan tindak pidana di Indonesia".

\footnotetext{
4 Muhadar, dkk. Perlindungan Saksi dan Korban dalam Sistim Peradilan Pidana. Putra Media Nusantara, Surabaya, 2010. HIm. 50

${ }^{5}$ Muhadar, dkk, Perlindungan Saksi dan Korban dalam Sistem Peradilan Pidana, Putra Media Nusantara, Surabaya, 2010, HIm. 236
} 


\section{Rumusan Masalah}

Berdasarkan latar belakang tersebut, maka rumusan masalah dalam penelitian ini adalah :

- Bagaimanakah pengaturan perlindungan hukum terhadap korban penganiayaan dalam peraturan perundang-undangan di Indonesia?

\section{Tujuan Penelitian}

Berdasarkan rumusan masalah tersebut di atas, maka tujuan penelitian yang hendak dicapai, adalah :

- Untuk menganalisis pengaturan perlindungan hukum terhadap korban penganiayaan dalam peraturan perundang-undangan di Indonesia.

\section{Manfaat Penelitian}

Dalam penelitian ini, diharapkan dapat dicapai beberapa manfaat baik dari aspek teoritis (keilmuan) maupun aspek praktis (guna laksana), sebagai berikut :

1. Secara teoritis, diharapkan hasil penelitian dapat dijadikan bahan referensi dalam pengembangan ilmu hukum khususnya dalam kajian hukum acara pidana.

2. Secara praktis, diharapkan hasil penelitian ini dapat memberikan masukan kepada semua pihak yang terkait dengan perlindungan hukum terhadap saksi dan korban dalam proses peradilan pidana termasuk para aparat penegak hukum dan pihak yang memiliki perhatian khusus dalam pengembangan sistem peradilan pidana yang bersih dan berwibawa serta memberikan perasaan keadilan bagi para pencari keadilan..

\section{B. TINJAUAN PUSTAKA}

\section{Perlindungan Hukum}

Perlindungan hukum berasal dari kata lindung yang artinya menempatkan diri di bawah sesuatu, supaya tersembunyi. Perlindungan memiliki pengertian suatu perbuatan yaitu melindungi, memberikan pertolongan. ${ }^{6}$ Sedangkan hukum menurut J.C.T. Simorangkir dan Woerjono Sastropranoto adalah peraturan-peraturan yang bersifat memaksa yang menentukan tingka laku manusia dalam lingkungan masyarakat yang dibuat oleh badan-badan resmi yang berwajib ${ }^{7}$

Menurut Philipus M. Hadjon, Pengertian perlindungan hukum dikaitkan dengan definisi perlindungan dan hukum adalah suatu perlindungan yang diberikan terhadap subjek hukum dalam bentuk perangkat hukum baik yang bersifat preventif maupun yang bersifat represif, baik yang tertulis maupun tidak tertulis. Perlindungan hukum sebagai suatu gambaran dari fungsi hukum, yaitu konsep di mana hukum dapat memberikan suatu keadilan, ketertiban, kepastian, kemanfaatan dan kedamaian. ${ }^{8}$

Menurut Satjipto Rahardjo bahwa perlindungan hukum berkaitan dengan penegakan hukum yaitu suatu proses tersendiri dalam masyarakat yang bertujuan untuk mempertahankan hukum dan ketertiban. ${ }^{\text {. }}$

Dalam negara hukum, perlindungan hukum mencerminkan kewajiban dan tanggung jawab yang diberikan dan dijamin oleh negara untuk menghormati, melindungi, menegakkan dan memajukan hak-hak asasi manusia berdasarkan Undang-Undang dan peraturan hukum.

Dalam pandangan Setiono tentang perlindungan hukum adalah tindakan atau upaya untuk melindungi masyarakat dari perbuatan sewenang-wenang oleh penguasa yang tidak sesuai

6 Peorwarminta, 1998, Kamus Bahasa Indonesia. Balai Pusataka : Jakarta HIm. 540

7 J.C.T. Simorangkir dan Woerjono Sastropratnoto, Hukum Indonesia. Pustaka Gunung Agung : Jakarta. HIm, 32

8 Philipus M. Hadjon. Perlindungan Hukum Bagi Rakyat di Indonesia, Sebuah Studi Tentang Prinsip-Prinsip Penerapannya Oleh Pengadilan Dalam Lingkungan Peradilan Umum dan Pembentukan Peradilan Administrasi Negara. Bina IImu. 1987. Surabaya. HIm. 1

9 Satjipto Raharjo, Penegakan Hukum Suatu Tinjauan Sosiologi. Genta Publishing : Jakarta. 2009. HIm 11 
dengan aturan hukum, mewujudkan ketertiban dan ketentraman sehingga memungkinkan manusia untuk menikmati martabatnya sebagai manusia. ${ }^{10}$

Salah satu fungsi hukum adalah untuk memberi perlindungan dimana hukum itu ditumbuhkan dan dibutuhkan manusia justru berdasarkan produk penelitian manusia untuk menciptakan kondisi yang melindungi dan memajukan martabat manusia serta untuk memungkinkan manusia menjalani kehidupan yang wajar sesuai dengan martabatnya. ${ }^{11}$

Montesquieu, dalam pandangannya mengenai negara menyatakan bahwa negara yang paling baik ialah negara hukum, sebab di dalam konstitusi di banyak negara mempunyai tiga inti pokok yaitu :

a) Perlindungan hak asasi manusia

b) Ditetapkannya ketatanegaraan suatu negara

c) Membatasi kekuasaan dan wewenang orang-orang negara. ${ }^{12}$

Di samping itu hukum adalah memperoleh setinggi-tinggi kepastian hukum (rechtzeker heid). Kepastian hukum menjadi makin dianggap penting bila dikaitkan dengan ajaran negara berdasarkan atas hukum. Telah menjadi klasik dalam ilmu hukum tertulis lebih menjamin kepastian hukum dibandingkan dengan hukum tidak tertulis.

Phlipus M. Hadjon, dalam pandangannya yang menempatkan perlindungan hukum sebagai sesuatu yang memungkinkan seseorang dapat melaksanakan dan mempertahankan hakhaknya yang ditentukan oleh hukum dan kaitanya tindakan pemerintah sebagai titik sentral maka Philips M. Hadjon, mengemukakan bahwa ada 2 (dua) macam perlindungan hukum bagi rakyat yaitu :

a) Perlindungan hukum yang preventif

Pada perlindungan hukum yang preventif, kepada rakyat diberikan kesempatan untuk mengajukan keberatan atau pendapatnya sebelum suatu keputusan pemerintah mendapat bentuk yang difinitif. Dengan demikian, perlindungan preventif bertujuan mencegah terjadinya sengketa.

b) Perlindungan hukum yang represif

Dalam perlindungan hukum yang represif, rakyat diberikan kesempatan mengajukan keberatan setelah adanya akibat dari suatu keputusan pemerintah yang definitif dalam arti bahwa perlindungan represif bersifat menyelesaikan masalah. ${ }^{13}$

Tahir Azhari, memperkenalkan pula istilah perlindungan hukum formal dan substantif . Perlindungan hukum formal adalah perlindungan hukum yang mangacu pada pelaksanaan hakhak dan secara formal diterapkan dalam peraturan perundang-undangan dan atau perjanjian. Perlindungan hukum subtantif adalah perlindungan hukum yang mengacu pada pelaksanaan hakhak yang secara subtantif melekat pada hukum. Artinya meskipun tidak diterapkan dalam undangundang namun pelaksanannya melekat pada orang/aktivitasnya. ${ }^{14}$

Negara hukum pada hakikatnya bersinggungan dengan persoalan tentang dua sentra kekuasaan. Di satu pihak terdapat negara dengan kekuasaan yang menjadi syarat mutlak untuk dapat memerintah. Di lain pihak nampak rakyat yang diperintah segan melepaskan segala kekuasaannya.

Van Apeldoorn, mengemukakan bahwa tujuan hukum ialah mengatur tata tertib masyarakat secara damai dan adil. Perdamaian di antara manusia dipertahankan oleh hukum dengan

10 Setiono. Rule Of Low (Supermasi Hukum). Surakarta. 2004. HIm. 3

11 Lili Rasjidi dan B. Arief Sidharta. Filsafat Hukum Madzab dan Refleksi. Remaja Rosida Karya : Bandung. 1994. HIm. 64

12 Judith N. Shklar. 1996. Montesqieau : Penggagas Trias Poltica www, Grafitti Com. Akses tanggal 15 Maret 2015

13 Philipus M. Hadjon. Perlindungan Hukum Bagi Rakyat Indonesia, Sebuah Studi Tentang Prinsipprinsipnya, Penerapannya oleh Pengadilan Dalam Lingkungan Peradilan Umum dan Pembentukan Peradilan Administrasi Negara. Bina Ilmu : Surabaya. 1987. HIm. 2

14 Muhammad Tahir Azhary. Negara Hukum Indonesia Analisis Yuridis Normatif Tentang Unsur-Unsurnya. U-Press : Jakarta. 1995. HIm. 1 
melindungi kepentingan-kepentingan manusia tertentu, kehormatan, kemerdekaan, jiwa harta dan sebagainya terhadap yang merugikannya. Kepentingan dari perorangan dan kepentingan golongan manusia selalu bertentangan satu sama lain, pertentangan kepentingan selalu menyebabkan pertikaian. Hukum mempertahankan perdamaian dengan menimbang kepentingan yang bertentangan secara teliti dan mengadakan keseimbangan diantaranya karena hukum hanya dapat mencapi tujuan (mengatur pergaulan hidup secara damai) jika ia menuju peraturan yang adil. Peraturan yang mengandung keseimbangan antara kepentingankepentingan yang dilindungi sehingga setiap orang memperoleh sebanyak mungkin yang menjadi bagiannya ${ }^{15}$.

Undang-Undang Nomor 13 Tahun 2006 tentang Perlindungan Saksi dan Korban memberikan perlindungan dan bantuan terhadap saksi maupun korban. Perlindungan dimaksud adalah dalam bentuk perbuatan yang memberikan tempat bernaung atau perlindungan bagi seseorang yang membutuhkan sehingga merasa aman terhadap ancaman sekitarnya. ${ }^{16}$

Berdasarkan Pasal 5 UU RI Nomor 13 Tahun 2006 tentang Perlindungan Saksi dan Korban disebutkan :

1. memperoleh perlindungan hukum atas keamanan pribadi, keluarga, dan harta bendanya, serta bebas dari ancaman yang berkenaan dengan kesaksian yang akan, sedang atau telah diberikannya ;

2. ikut serta dalam proses memilih dan menentukan bentuk perlindungan dan dukungan keamanan ;

3. memberikan keterangan tanpa tekanan ;

4. mendapat penerjemah ;

5. bebas dari pertanyaan yang menjerat ;

6. mendapat informasi mengenai perkembangan kasus ;

7. mendapat informasi mengenai putusan pengadilan ;

8. mengetahui dalam hal terpidana dibebaskan ;

9. mendapat identitas baru ;

10. mendapatkan tempat kediaman baru;

11. memperoleh penggantian biaya tranfortasi sesuai dengan kebutuhan ;

12. mendapat nasehat hukum ; dan /atau

13. memperoleh bantuan biaya hidup sementara sampai batas waktu perlindungan terakhir.

Menurut ketentuan Pasal 6 Undang-Undang Perlindungan Saksi dan Korban menentukan bahwa korban dalam pelanggaran HAM yang berat, selain berhak atas hak sebagaimana dimaksud dalam Pasal 5, juga berhak untuk mendapatkan :

1. Bantuan medis;

2. Bantuan rehabilitasi psiko-sosial.

Demikian juga ketentuan Pasal 7 Undang-Undang Perlindungan Saksi dan Korban menentukan :

1. Korban melalui LPSK berhak mengajukan ke pengadilan berupa :

a. hak atas kompensasi dalam kasus pelanggaran hak asasi manusia yang berat ;

b. hak atas restitusi atau ganti kerugian yang menjadi tanggungjawab pelaku tindak pidana.

2. Keputusan mengenai konpensasi dan retitusi diberikan oleh pengadilan

3. Ketentuan lebih lanjut mengenai pemberian kompensasi dan restitusi diatur dengan Peraturan Pemerintah.

Ketentuan-ketentuan mengenai perlindungan terhadap korban tindak pidana di dalam Kitab Undang-Undang Hukum Acara Pidana lebih dominan memberikan pengaturan mengenai ganti rugi yang dapat dikelompokkan dalam 4 (empat) bentuk hak-hak korban yaitu: ${ }^{17}$

15 Van Apeldoorn dalam ibid. HIm. 89

16 Muhadar dkk. Perlindungan Saksi dan Korban Dalam Sistem Peradilan Pidana. Putera Media Nusantara : Surbaya. 2010. HIm. 104

${ }^{17}$ Muhaddar dkk. Perlindungan Saksi dan Korban Dalam Sistem Peradilan Pidana, Putra Media 
a. Hak untuk melakukan kontrol terhadap tindakan penyelidik dan penuntut umum, yakni hak mengajukan keberatan atas tindakan penghentian penyelidikan dan/atau penuntutan dalam kapasitasnya sebagai pihak ketiga yang berkepentingan sebagaimana diatur dalam Pasal 109 dan 140 ayat (2) KUHAP;

b. Hak korban dalam kedudukannya sebagai saksi, sebagaimana diatur dalam Pasal 168 KUHAP;

c. Hak bagi korban, untuk mengizinkan atau tidak mengizinkan polisi atas tindakan polisi melakukan bedah mayat atau penggalian kubur untuk otopsi Hal ini di atur dalam Pasal 134 sampai 136 KUHAP.

d. Hak menuntut ganti rugi atas kerugian yang diberikan dari akibat tindak pidana dalam kapasitasnya sebagai pihak yang dirugikan sebagaimana diatur dalam Pasal 98 sampai dengan Pasal 101 KUHAP.

Kelemahan pengaturan Kitab Undang-Undang Hukum Acara Pidana (KUHAP) dalam mengatur mengenai korban dalam pandangan Barda Nawawi Arief ${ }^{18}$ adalah sebagai berikut :

a. Tidak ada upaya hukum yang dapat dilakukan korban jika tidak puas dengan suatu putusan pengadilan. Hal ini berbeda dengan tersangka, yang dapat melakukan upaya hukum banding, kasasi, ataupun peninjauan kembali. Korban yang diwakili oleh jaksa sebagai penuntut umum hanya bisa menerima putusan tersebut.

b. Perlindungan terhadap korban kejahatan hanya diatur di dalam Bab XII (Pasal 98-101) KUHAP, yang memungkinkan penggabungan perkara gugatan ganti kerugian kepada perkara pidana.

c. Pasal 99 KUHAP menegaskan bahwa ganti kerugian yang dapat diputuskan oleh Hakim hanyalah biaya lainnya hanya dapat digugat melalui peradilan perdata yang prosesnya memakan waktu yang lama dan memulai procedural acara baru.

d. Hakim dapat menetapkan syarat khusus bahwa terpidana dalam waktu tertentu, yang lebih pendek dari pada masa percobannya, harus mengganti seluruh atau sebagai kerugian yang ditimbulkan oleh tindak pidana tersebut atau dengan kata lain bahwa hak korban tindak pidana kejahatan hanya berlaku bila Hakim menjatuhkan hukuman percobaan sedangkan dalam hal kejahatan yang menimbulkan kerugian besar atau kejahatan dengan kekerasan, hukuman percobaan sulit untuk dijatuhkan.

e. Pembayaran yang dibebankan kepada pelaku berupa ganti kerugian dibatasi hanya atas nilai yang bersifat materil.

\section{Konsepsi Tentang Korban}

a. Defenisi Korban

Secara istilah korban berasal dari bahasa latin victim dalam Declaration of Bacic Principles of Justice for Victims of Crime and Abuse of Power adalah orang baik secara individu maupun kolektif telah menderita kerugian baik fisik, mental, emosional maupun pembusukan (imparirment) terhadap hak-hak dasar mereka baik melalui perbuatan maupun tidak, namun merupakan pelanggaran terhadap hukum pidana nasional di samping juga berdasarkan normanorma internasional diakui berkaitan dengan hak asasi manusia ${ }^{19}$

Korban adalah merupakan orang yang mengalami kerugian baik kerugian fisik, mental maupun kerugian finansial yang merupakan akibat dari satu tindak pidana (sebagai akibat) atau merupakan sebagai salah satu faktor timbulnya tindak pidana (sebagai sebab). Korban diartikan

\footnotetext{
Nusantara Surabaya, 2010, HIm 51

18 Barda Nawawi, Perbandingan Hukum Pidana, Raja Grafindo Persada, Jakarta, 2002 hlm.6

19 Benjamin Mendelsohn dalam Ira Dwiati. 2007. Perlindungan Hukum Terhadap Korban Tindak Pidana Perkosaan Dalam Peradilan Pidana. HIm. 76
} 
sebagai seseorang yang telah menderita kerugian sebagai akibat tindak pidana dan rasa keadilannya secara target/sasaran tindakan pidana". ${ }^{20}$

Stanciu, menyebutkan bahwa korban dalam pengertian yang luas adalah orang yang menderita akibat dari ketidakadilan. Ada dua sifat yang mendasar yang melekat pada korban yaitu pertama yang disebut suffering (penderitaan) dan injustice (ketidakadilan). Korban tidak hanya dapat dipandang sebagai akibat perbuatan yang illegal sebab sebenarnya juga dapat menimbulkan ketidakadilan, selanjutnya menimbulkan korban. Pengertian dibatasi pula dalam arti sempit sebagaimana diatur dalam hukum positif. ${ }^{21}$

Hukum positif indonesia yang memberikan definisi tegas mengenai korban antara lain adalah Pasal 1 angka 2 Undang-Undang Perlindungan Saksi dan Korban yang menyebutkan bahwa korban adalah seseorang yang mengalami penderitaan fisik, mental, dan/atau kerugian ekonomi yang diakibatkan oleh suatu tindakan pidana.

Declaration of Basic Principles of Justice for Victims of Crime and Abuses of Power mendefinisikan korban sebagai

berikut :

Victims" means persons who, individually, or collectivey, have

suffered harm, including physical or mental injury,emotionalsuffreing, economic loss or subtansial imparitment of eheir fundamental rights, through acts or omissions that are in violation of criminal laws operative within member states, inclunding those laws proscribing criminal abuse of power.

Definisi di atas menunjukakan bahwa korban kejahatan diartikan sebagai orang yang secara perorangan atau bersama-sama, menderita kerugian, termasuk kerugian fisik atau mental, penderitaan emosional, kerugian ekonomis atau pelemahan substansial dari hak-hak dasar mereka, melalui tindakan atau kelalaian yang merupakan penggaran terhadap hukum yang berlaku di negara-negara anggota termasuk hukum-hukum yang melarang penyalahgunanan kekuasaan yang bersifat pidana. ${ }^{22}$

\section{b. Jenis-Jenis Korban dan Perlindungan Korban}

Konsepsi korban tindak pidana termasuk juga dalam Declaration of Basic Principlesof Justice for Victim of Crime and Abuse of Power, Power, yaitu :23

a. Korban tindak pidana (victim of crime) meliputi :

1) Korban Langsung (direct victims) yaitu korban yang langsung mengalami dan merasakan penderitaan dengan adanya tindak pidana dengan karakteristik korban adalah orang baik secara individu atau kolektif, menderita kerugian berupa luka fisik, luka mental, penderitaan emosional, kehilangan pendapatan dan penindasan hak-hak dasar manusia, disebabkan adanya perbuatan atau kelalaian yang terumuskan dalam hukum pidana atau disebabkan adanya penyalagunaan kekuasaan.

2) Korban tidak lansung (indirect victims) yaitu timbulnya korban akibat dari campurnya seseorang dalam membantu korban langsung (direct victims) atau turut melakukan pencegahan timbulnya korban, tetapi dia sendiri menjadi korban tindak pidana, atau mereka menggantungkan hidupnya kepada korban langsung seperti isteri/suami, anak-anak dan keluarga terdekat.

3) Victims of abuse of power yaitu korban adalah yang secara individual atau kolektif menderita kerugian, termasuk luka fisik atau mental, penderitaan emosional, kehilangan ekonomi atau pelanggaran terhadap pokok-pokok hak dasar mereka,

20 Sujoko. Implementasi Tuntutan Ganti Kerugian dalam Pasal 98 KUHP Terhadap Tindak Pidana Pemerkosaan. Universitas Dipenorogo. 2008. HIm. 1

21 V.V. Stanciu dalam ibid. HIm. 29.

22 United Nation Declaration of Basic Principles of Victims of Crime and Abuse of Power 29 November 1985. File Naska deklarasi di download dari http:/www.unrol,org/filea/BASICP-4PDF.

23 Bambang Djoyo Supeno. Penerapan Hukum Bagi Koruptor Masih Timpang. Semarang. HIm. 2 
melalui perbuatan-perbuatan atau kelalaian yang belum merupakan. pelanggaran undang-undang pidana nasional tetapi norma-norma diakui secara internasional yang berhubungan dengan hak-hak asasi manusia.

Mardjono Reksodiputro, mengemukakan pula pandangan bahwa ada 4 (empat) macam pengertian korban yaitu. ${ }^{24}$

1. Korban kejahatan konvesional seperti pembunuhan, perkosaan, penganiayaan, pencurian

2. Korban kejahatan non konvesional seperti terorisme, pembajakan, perdagangan narkotika secara tidak sah, kejahatan terorganisasi dan kejahatan melalui computer.

3. Korban penyalagunaan secara melawan hukum kekuasaan ekonomi (illegal abuses of economic power) seperti pelanggaran terhadap peraturan perburuhan, penipuan konsumen, pelanggaran terhadap peraturan lingkungan, penyelewengan di bidang pemasaran dan perdagangan oleh perusahaan-perusaan trans-nasional, pelanggaran peraturan devisa, pelanggaran peraturan pajak dan sebagainya.

4. Korban penyalahgunaan secara melawan hukum kekuasaan umum (illegal abuses of public power) seperti pelanggaran terhadap hak asasi manusia, penyalahgunaan wewenang oleh alat penguasa, termasuk penangkapan serta penahanan yang melanggar hukum dan lain sebagainya

Sellin dan Wolf dalam Bedi Setiawan Al Fahmi, membuat klasifikasi korban menjadi 5 (lima) golongan, yaitu :25

1) Viktimisasi primer, yaitu korban individual. Jadi korban orang perorangan atau bukan kelompok.

2) Viktimisasi sekunder, dimana yang menjadi korban adalalh kelompok seperti badan hukum.

3) Viktimisasi mutual, terjadi karena sikap atau perilaku korban yang menyetujui terjadinya kejahatan terhadap dirinya.

4) Viktimisasi tertier korban yang timbul akibat adanya penyelenggaraan tertib sosial.

5) Tidak ada viktimisasi, di sini bukan berarti tidak ada korban yang timbul, melainkan korban tidak segera dapat diketahui.

Steven Schafer dalam Rena Yulia dalam kaitannya dengan peranan korban mengemukakan beberapa tipe korban yang dikaitkan dengan pertanggungjawaban, yaitu ${ }^{26}$,:

1) Unrelated victims, adalah mereka yang tidak mempunyai hubungan apapun dengan pelaku kecuali pelaku yang telah melakukan kejahatan terhadapnya. Pada tipe ini tanggung jawab terletak penuh di tangan pelaku.

2) Provocative victims adalah mereka yang melakukan sesuatu terhadap pelaku dan konsekuensinya mereka menjadi korban. Korban dalam hal ini merupakan pelaku utama. Pada tipe ini yang bertanggungjawab terletak pada dua belah pihak yaitu korban pelaku.

3) Precitative victims, merupakan perilaku korban yang tanpa disadari mendorong pelaku untuk berbuat jahat. Pada tipe ini tanggng jawab terletak pada pelaku.

4) Biologically weak vitimas, adalah mereka yang mempunyai bentuk fisik dan mental tertentu yang mendorong orang melakukan kejahatan terhadapnya, sebagai contoh anak kecil, orang kecil orang berusia lanjut, perempuan, orang yang cacat fisik mental. Pada tipe ini yang bertanggung jawab adalah masyarakat dan pemerintah, karena tidak mampu melindungi

korban yang tidak berdaya.

24 Mardjono Reksodiputro. Kriminolgi dan Sistem Peradilan Pidana (Kumpulan Karangan, buku kedua), Pusat Pelayanan Keadilan dan Pengabdian Hukum (d/h Lembaga Kriminologi) Universitas Indonesia : Jakarta. 2007. HIm. 8586

${ }^{25}$ Bedi Seiawan Al Fahmi. Perlindungan Korban Tindak Pidana Perkosaan Dalam Proses Peradilan Pidana Perspektif Pembaharuan Hukum Acara Pidana Indonesia. Jurnal Hukum dan Pembangunan No. 1 Vol. 16 Januari 2009. Badan Penerbit FH. UI : Depok. 2009. HIm. 65.

26 Rena Yulia. 2011. Viktimologi: Perlindungan Hukum Terhadap Korban Kejahatan. HIm 164-165. Jurnal Intelek Volume 7 tanggal 3 Desember 2011. Pusat Penerbitan Universitas Teknologi MARA. HIm. 54 
5) Socially wek vctims, adalah mereka yang tidak diperhatikan oleh masyarakat sebagai anggota, misalnya kaum imigran dan kelompok minoritas. Pada tipe ini pertanggung jawaban terletak pada penjahat dan masyarakat.

6) Self-vitimizing victims adalah mereka yang menjadi korban karena perbuatannya sendiri, seperti kecanduan narkotika, homo seksual dan perjudian. Pada tipe ini tanggung jawab terletak penuh pada pelaku juga menjadi korban.

7) Political victims adalah mereka yang menderita karena lawan politiknya. Pada tipe ini ada yang dapat dipertanggung jawabkan.

Barda Nawawi Arief, mengemukakan bahwa dalam hukum pidana positif yang berlaku pasa saat ini perlindungan korban lebih banyak merupakan "perlindungan abstrak" atau "perlindungan tidak langsung" artinya berbagai rumusan tindak pidana dalam peraturan perundang-undang selama ini pada hakekatnya telah ada perlindungan in abstracto secara langsung terhadap kepentingan hukum dan hak asasi korban ${ }^{27}$.

Pasal 1 Angka 6 Undang-Undang Nomor 13 tahun 2006 tentang perlindungan saksi dan korban menegaskan bahwa perlindungan adalah segala upaya pemenuhan hak dan pemberian bantuan untuk memberikan rasa aman kepada saksi dan/korban yang wajib dilaksanakan oleh LPSK (Lembaga Perlindungan Saksi dan Korban) atau Lembaga lainnya sesuai dengan ketentuan undang-undang ini. Pengertian perlindungan korban dapat dilihat dari 2 (dua) makna :28

1. Diartikan sebagai perlindungan hukum untuk tidak menjadi korban kejahatan (berarti perlindungan Hak Asasi Manusia (HAM) atau kepentingan hukum seseorang).

2. Diartikan sebagai perlindungan untuk memperoleh jaminan/santunan hukum atas penderitaan/kerugian orang yang menjadi korban (identik dengan penyantunan korban).

Bentuk santunan itu dapat berupa pemulihan nama baik/rehabilitasi, pemulihan keseimbangan batin antara lain dengan pemaafan, pemberian ganti rugi seperti restitusi, kompensasi, jaminan/santunan kesejahteraan sosial dan sebagainya.

Tujuan perlindungan korban adalah memberikan ketentraman rasa aman kepada korban khususnya pada saat memberikan keterangan pada setiap proses peradilan pidana, memberikan dorongan dan motivasi kepada korban agar tidak takut dalam menjalani proses peradilan pidana, memulihan rasa percaya diri korban dalam hidup bermasyarakat, dan memulai rasa keadilan, bukan hanya kepada korban dan keluarga korban, tapi juga kepada masyarakat $^{29}$

Secara umum dalam teori dikendalikan dua model perlindungan terhadap korban yaitu : ${ }^{30}$

\section{Model hak prosedur (The procedural rights model)}

Di Perancis model ini di sebut "partice civile model" (civil action system). Secara singkat model ini menekankan dimungkinkan beberapa aktifnya korban dalam proses peradilan pidana seperti membantu jaksa penuntut umum, dilibatkan dalam setiap tingkat pemeriksaan perkara, wajib didengar pendapatnya apabila terpidana dilepas bersyarat, dan lain sebagainya.

Selain itu, dengan turut sertanya secara aktif dalam proses peradilan pidana, korban bisa mendapatkan kembali harga diri dan kepercayaan dirinya. Keterlibatan korban mempunyai segi positif dalam penegakan hukum, dan mempunyai segi negatif karena partisipasi aktif korban dalam pelaksanaan proses peradilan pdana dapat menyebabkan kepentingan pribadi terletak di atas kepentingan umum.

27 Barda Nawawi Arief. Masalah Penegakan Hukum dalam Kebijakan Hukum Pidana Dalam Penanggulangan Kejahatan. PT. Citra Aditya Bakti : Bandung. 2001. HIm. 56.

28 Theodora Shah Putri. Upaya Perlindungan Korban Kejahatan melalui Lembaga Restitusi dan Kompensasi. Fakultas Hukum Indonesia. www.pemantauperadilan.com, akses tanggal 27 Juni 2014

29 Pasal 4 UU No. 13 Tahun 2006 Tentang Perlindungan Saksi dan Korban

30 Ahmad Kamil. Mediasi Penal dalam Penanganan Tindak Pidana. Mahkama Agung Republik Indonesia : Jakarta. 2012. HIm. 4 
Selanjutnya alasan lain dikemukakan kelompok yang menentang diberikan hak prosedural korban adalah dengan di berikannya peran individual kepada korban dalam proses persidangan atau penentutan terhadap pelaku, berarti membuatnya bertanggung jawab atas jalanya persidangan serta hasil dari proses itu. Seningga beban tanggung jawab ini menjadi tekanan yang cukup berat bagi korban dalam berbagai segi. Tekanan bisa muncul dari orang dengan siapa korban melakukan kontak dan/atau disebabkan oleh polisi atau jaksa yang akan memanfaatkan hak-haknya untuk kepentingan umum. Pelaku dan pengacaranya akan berusaha mempengaruhi tingkah laku korban selama proses dan kadang dengan menggunakan intimidasi.

\section{Model pelayanan (the services model)}

Model ini menekankan pada pemberian ganti kerugian dalam bentuk kompensasi, restitusi dan upaya pengambilan kondisi korban yang mengalami trauma, rasa takut dan tertekan akibat kejahatan. Kebijakan perumuan sistem pemidanaan yang beorientasi pada korban dalam hukum positif yang akan datang meliputi kebijakan perumusan perlindungan korban dalam hukum pidana materil, kebijakan perumusan perlindungan korban dalam hukum pidana formil dan kebijakan perumusan perlindungan korban dalam hukum pelaksanaan pidana. substansi hukum positif yang dimaksud adalah Rancangan Undang-Undang tentang Kitab Undang-Undang Hukum Pidana Tahun 2008 dan Rancangan Undang-Undang Kitab Undang-Undang Hukum Acara Pidana tahun 2009.

Pidana tambahan dalam rancangan KUHAP dalam penjelasan Pasal 67 ayat (1) diartikan sebagai "pembayaran ganti kerugian" yang dapat dijatuhkan hakim hanyak jika "tercantum secara jelas dalam rumusan tindak pidana". Ketentuan pasal 54 rancangan KUHAP menegaskan bahwa pemidanaan diantaranya menyelesaikan konflik yang ditimbulkan oleh tindak pidana, memulihkan keseimbangan, dan mendatangkan rasa damai dalam masyarakat".

Ketentuan pasal 55 ayat (1) menentukan bahwa pedoman pemidanaan yang harus dipertimbangkan hakim diantaranya pengaruh tindak pidana terhadap korban atau keluarga korban, pemaafaatan dari korban dan/atau keluargannya. Penjelasan ketentuan pada ayat (1) ini memuat pedoman pemidanaan yang sangat membuat hakim dalam mempertimbangkan takaran atau berat ringannya pidana yang akan dijatuhkan. Dengan mempertimbangkan hal-hal yang dirinci dalam pedoman tersebut diharapkan pidana dijatuhkan bersifat proposional dan dapat dipahami baik oleh masyarakat maupun terpidana. Rincian dalam ketentuan ini tidak bersifat limitatif, artinya hakim dapat menambahkan pertimbangan lain selain yang tercantum pada ayat (1) ini.

Ketentuan pasal 71 huruf $\mathrm{c}$, $\mathrm{d}$ dan $\mathrm{g}$ menentukan bahwa "dengan tetap mempertimbangkan pasal 54 dan Pasal 55, pidana penjara sejauh mungkin tidak dijatuhkan, jika dijumpai keadaan-keadaan sebagai berikut : diantaranya 1. Kerugian dan penderitaan korban tidak terlalu besar 2. Terdakwa telah membayar ganti kerugian kepada korban 3. Korban tindak pidana mendorong terjadinya tindak pidana tersebut". Penjelasan pasal 71 menegaskan bahwa ketentuan dalam pasal 71 dimaksudkan untuk membantu hakim dalam menentukan takaran pidana yang akan dijatuhkan.

Pasal 54 dan pasal 55 memberikan pedoman agar hakim dapat menjatuhkan pidana secara proporsional dan efektif dan ketentuan pasal 71 ini sebagai aturan pemidanaan bagi hakim dalam hal tidak akan menjatuhkan pidana penjara dalam kondisi yang dijelaskan dalam pasal 71 tersebut. Formulasi ketentuan pasal 77 ini tidak operasional karena tidak terdapat "ketentuan jenis pidana yang dapat dijatuhkan hakim" setelah dia tidak menjatuhkan pidana penjara. Ketentuan demikian juga tidak tercantum dalam penjelasan. Ketentuan pasal 65 ayat (1) di bawah paragrap "jenis pidana" disamping penjara, tercantum juga sebagai pidana pokok yaitu : tutupan, pengawasan, denda dan kerja sosial. Persoalannya jika ketentuan pasal 71 terpenuhi, jenis pidana apa yang dapat dijatuhkan hakim proporsional dan efektif.

Penerapan ganti rugi terhadap korban tindak pidana telah diterapkan oleh negara lain terutama yang menganut sistem hukum Anglo Saxon. Selandia Baru merupakan salah satu contoh negara yang mengenal ganti rugi terhadap korban dalam pengaturan hukumanya. Di Selandia Baru, ganti rugi terhadap korban telah disahkan sebagai salah satu jenis pidana dalam peraturan perundang-undangnya. Hal ini dilatarbelakangi oleh pandangan mereka bahwa 
dalam hal penderitaan atau kerugian yang bersifat materil yang dialami oleh korban sebagai akibat dari perbuatan pidana yang dilakukan oleh orang lain, sepantasnyalah pelaku perbuatan pidana (orang lain tersebut) yang menyediakan ganti rugi itu. ${ }^{31}$

\section{c. Faktor Yang Mempengaruhi Perlindungan Hukum terhadap Korban Kejahatan}

Setiap norma hukum sudah dengan sendirinya mengandung kebutuhan tentang hak-hak dan kewajiban-kewajiban para subyek hukum dalam lalu lintas hukum. Norma-norma hukum yang bersifat dasar, tentulah berisi rumusan hak-hak dan kewajiban-kewajiban yang juga dasar dan mendasar. Oleh karena itu, secara akademis, sebenarnya persoalan hak dan kewajiban asasi manusia memang menyangkut konsepsi yang niscaya ada dalam keseimbangan konsep hukum dan keadilan. Dalam setiap hubungan hukum terkandung di dalamnya dimensi hak dan kewajiban secara pararel dan bersilang. Kekuasaan yang diorganisasikan ke dalam dan melalui organ-organ negara, seringkali terbukti melahirkan penindasan . oleh karena itu, sejarah umat manusia mewariskan gagasan perlindungan dan penghormatan terhadap hak-hak asasi manusia.

Marwanto Heru Santoso ${ }^{32}$ mengemukakan bahwa gagasan perlindungan dan penghormatan hak asasi manusia ini bahkan diadopsi ke dalam pemikiran mengenai pembatasan kekuasan yang kemudian dikenal dengan aliran konstitusionalisme, aliran konstitusionalisme inilah yang memberi warna modern terhadap ide-ide demokrasi dan nomokrasi (negara hukum) dalam sejarah, sehingga perlindungan konstitusional terhadap hak asasi manusia dianggap sebagai ciri utama yang perlu ada dalam setiap negara hukum yang demokratis (demoocratitutional rechsstaat) ataupun negara demokrasi yang berdasar pada hukum (constitutional democracy).

Pembahasan mengenai negara hukum dikemukakan oleh Brian Z. Tamanaha, bahwa $:^{33}$ They all emphasize that the primary valuve of the rule of law the essence of what it does is to provide predictability thereby allowing people to plan and that this highly valued because it enhances individual autonomy. Above all, the rule of law is about legal liberaty. Another point of unanimity is that the rule of law is meutral with regard to a wide range of alternative sunbstantive content. Fuller asserted that his notion of legality was "indifferent toward the substantive aims of the law and is ready to serve a variety of such aims with equal efficiency..

(Nilai utama esensi aturan hukum adalah untuk memberikan prediktabilitas, sehingga menungkinkan orang untuk merancanakan, dan bahwa hal ini sangat dihargai karena meningkatkan otonomi individu). Namun tidak hanyak cukup dengan mencakup jauh lebih pada substansi kepastian, kejelasan, publisitas, propektivitas, teori ini menekankan bahwa unsurunsur ini diperlukan bahwa hukum sebagai sesuatu yang disahkan adalah tidak boleh secara teratur menyimpang dari aturan-aturan untuk mencapai keadilan substantive.

Gunther Teubner, ${ }^{34}$ yang mengemukakan bahwa ada 3 (tiga) model tingkat perkembangan hukum dalam masyarakat modern, yaitu (1) The formal rationality, dimana hukum berorientasi kepada aturan dan dedukatif; (2) The substantive rationality dimana hukum ditujukan untuk mengatur aktivitas ekonomi dan sosial dalam rangka kompensasi terhadap kekurangan pasar dan diterapkannya melalui regulasi, standar, dan prinsip-prinsip; dan (3) the reflective rationality, dimana kemunculan jenis rasionalitas yang menggantikan dua rasionalitas sebelumnya. The reflextive rationality memandang bentuk regulasi self-regulation ini merupakan bentuk ideal. Pemikiran hukum berorientasi pada prosedur. Tugas utama hukum tidak memberi isi, tapi membuat premis struktural untuk terjadinya proses self-regulation. Hukum hanya menetapkan keputusan (decide about decision), mengatur regulasi (regulate regulation) dan menetapkan premis strutural untuk keputusan di masa yang akan datang dalam hal organisasi, prosedur dan kompensasi.

\footnotetext{
${ }^{31}$ Roeslan Saleh. Segi Lain Hukum Pidana. Ghalia Indonesia : Jakarta. 1984. HIm. 21

32 Marwanto Heru Santoso. Polisi dalam Era Reformasi, Makala : Jakarta. 1998. HIm. 13

${ }^{33}$ Brian Z. Tamanaha. The Rule Of Law Theory, Oxford Univesity : New York. HIm. 53.

34 Dalam Lan Ayeres and John Braihwaite. Responsive Regulation : Transcending the Derugulation Debate. Oxford University Press : Oxford. 1992. HIm. 4
} 
Pandangan di atas, menunjukan bahwa setelah substansi hukum maka penegak hukum. Aparatur penegak hukum mencakup pengertian mengenai institusi penegak hukum dan aparat (orangnya) penegak hukum.

Aparatur penegak hukum dalam arti sempit adalah pihak yang terlibat dalam tegaknya hukum itu, dimulai dari saksi, polisi, penasehat hukum, jaksa hakim dan petugas-petugas sipir permasyarakatan. Setiap aparat dan aparatur terkait mencakup pula pihak-pihak yang bersangkutan dengan tugas atau perannya yaitu terkait dengan kegiatan pelapor atau pengaduan, penyeledikan, penyidikan, penuntutan, pembuktian, penjatuhan vonis dan pemberian sanksi, serta upaya pemasyarakatan kembali (resosialisasi) terpidana. ${ }^{35}$

Dalam proses bekerjanya aparatur penegak hukum itu, terdapat 3 (tiga) elemen penting yang mempengaruhi, yaitu: ${ }^{36}$

a. Institusi penegak hukum beserta berbagai perangkat sarana dan prasarana pendukung dan mekanisme kerja kelembagaannya;

b. Budaya kerja yang terkait dengan aparatnya, termasuk mengenai kesejahteraan aparatnya, dan

c. Perangkat peraturan yang mendukung baik kinerja kelembagaannya maupun yang mengatur material hukum yang dijadikan standar kerja, baik hukum materilnya maupun hukum acaranya.

Upaya penegak hukum secara sistematik haruslah memperhatikan ketiga aspek itu secara simultan, sehingga proses penegakan hukum dan keadilan itu sendiri secara internal dapat diwujudkan secara nyata.

Hikmahanto Juwana, mengemukakan bahwa bagi masyarakat Indonesia, lemah kuatnya penegakan hukum oleh aparat akan menentukan persepsi ada tidaknya hukum. Bila penegakan hukum oleh aparat lemah, masyarakat akan memeprsepsikan hukum sebagai tidak ada seolah mereka berada dalam hutan rimba. Sebaliknya, bila penegakan hukum oleh aparat kuat dan dilakukan secara konsisten, barulah masyarakat mempersepsikan hukum ada dan akan tunduk. ${ }^{37}$

Aparatur penegak hukum mencakup pengertian mengenai institusi penegak hukum dan aparat (orangnya) penegak hukum. Dalam arti sempit, aparatur penegak hukum yang terlibat tegaknya hukum itu, dimulai dari saksi, polisi, penasehat hukum, jaksa, hakim, dan petugaspetugas sipir pemasyarakatan. Setiap aparat dan aparatur terkait mencakup pula pihak-pihak yang bersangkutan dengan tugas atau perannya yaitu terkait dengan kegiatan pelaporan atau pengaduan, penyelidikan, penyidikan, penuntutan, pembuktian, penjatuhan vonis dan pemberian sanksi, serta upaya pemasyarakatan kembali (resosialisasi) terpidana. ${ }^{38}$

Masyarakat Indonesia masih dalam taraf masyarakat yang "takut" pada hukum (aparat penegak hukum) dan belum dapat dikategorikan sebagai masyarakat sebagai yang 'taat' pada hukum. Pada masyarakat yang takut pada hukum, masyarakat tidak akan tunduk pada hukum bila penegakan hukum lemah, inkonsisten dan tidak dapat dipercaya. Realitas saat ini penegakan hukum berfungsi dan difungsikan sebagai instrumen untuk membuat masyarakat takut pada hukum yang pada gilirannya

diharapkan menjadi taat pada hukum. ${ }^{39}$

Keluhan berkenaan dengan kinerja penegakan hukum di Indonesia selama ini, sebenarnya juga memerlukan analisis yang lebih menyeluruh lagi. Upaya penegakan hukum hanya satu elemen saja dari keseluruhan persoalan kita sebagai negara hukum yang mencitacitakan upaya menegakkan dan mewujudkan keadilan sosial bagi seluruh rakyat Indonesia. Hukum tidak mungkin akan tegak, jika hukum itu sendiri tidak atau belum mencerminkan perasaan atau nilai-nilai keadilan yang hidup dalam masyarakatnya, hukum tidak mungkin menjamin keadilan jika materinya sebagian besar merupakan warisan masa lalu yang tidak

\footnotetext{
${ }^{35}$ Wijayanto dan Ridwan Zachrie. Korupsi Mengerupsi Indonesia. PT. Gramedia :Jakarta. HIm.3

${ }^{36}$ Ibid HIm. 4

37 Hikmahanto Juwana. Penegakan Hukum Bidang Lalu Lintas. Citra Pratama: Jakarta. 2001. HIm.11

38 Muiz Thohir. Lalu Lintas di Indonesia, Sinar Persada : Jakarta. 1999. HIm. 65

39 Prabowo dan Dwi Riyanti. Masalah Kejiwaan dalam Berbagai Profesi. Sinar Grafika:Jakarta.1998. HIm. 2
} 
sesuai lagi dengan tuntutan zaman. Persoalan yang dihadapi bukan saja berkenaan dengan upaya penegakan hukum tetapi juga pembaharuan hukum atau pembuatan hukum baru. ${ }^{40}$

Ada 4 (empat) fungsi penting yang memerlukan perhatian yang seksama, yaitu : ${ }^{41}$

a. Pembuatan hukum (the legislation of law atau law and rule making),

b. Sosialisai, penyebarluasan dan bahkan pembudayaan hokum (socialization and promulgation of law) dan

c. Penegakan hukum (the enforcement of law)

Ketiganya membutukan dukungan (d) administrasi hukum (the administration) yang efektif dan efisien yang dijadikan oleh pemerintah (eksekutif) yang bertanggung jawab (accountable). Karena itu, pengembangan administrasi hukum dan sistem hukum dapat disebut sebagai agenda penting yang keempat sebagai tambahan terhadap ketiga agenda tersebut di atas.

The administration of law itu mencakup pengertian pelaksanaan hukum (rules executing) dan tata administarsi hukum itu sendiri dalam dalam pengertian yang sempit. Misalnya dapat dipersoalkan sejauh mana sistem ini telah dikembangkan dalam rangka pendokumentasian peraturan-peraturan (rege/s), keputusan-keputusan administrasi negara (beschikings), ataupun penetapan dan putusan (vonis) hakim di seluruh jajaran dan lapisan pemerintahan dari pusat sampai ke daerah-daerah. ${ }^{42}$

Untuk memahami secara lebih cermat tentang sistem hukum, maka harus dicermati unsur-unsur yang terdapat di dalam sistem hukum itu. Sistem hukum mempunyai tiga unsur yaitu struktur, substansi dan kultur. Sebagaimana dinyatakan oleh Lawrence M. Friedman bahwa :

"A legal system in actual operation is a complex organism in which structure, substance, and culture interact. To explainthe background and effect of any part calls into play many elementsof the system. ${ }^{43 "}$

Pandangan diatas menunjukkan bahwa sistem hukum dalam kegiatangnya menjalankan sebenarnya merupakan gabungan struktur, substansi, dan budaya yang saling berhubungan dan menjelaskan begitu banyaknya unsur sistem. Selanjutnya Sudikno Mertokusumo ${ }^{44}$, menyatakan, bahwa dalam penegakan hukum hanya diperhatikan kepastian hukum saja, maka unsur-unsur lainnya dikorbankan. Demikian pula kalau yang diperhatikan hanyalah kemanfaatannya, maka kepastian hukum dan keadilan dikorbankan dan perhatian secara proposional seimbang akan tetapi, dalam praktik tidak selalu mudah mengusahakan kompromi secara proposional seimbang antara ketiga unsur tersebut.

Daniel S. Lev dalam Satjipto Rahardjo., yang menyatakan, bahwa apabila kekuatan para pejabat hukum seperti Hakim, Jaksa, Polisi dan Advokat berubah, maka hal itu berarti hukum juga sudah berubah, walaupun undang-undang dan peraturan-peraturan lainnya masih tetap saja seperti dahulu. Hukum yang dimaksudkan Daniel S. Lev dalam hal ini, adalah bukan undang-undang dan peraturan-peraturan hukum yang anggapnya sebagai pengertian yang sempit, tetapi yang merupakan hukum adalah praktik sehari-hari oleh para pejabat hukum itu. ${ }^{45}$

Selanjutnya menurut Soerjono Soekanto, terdapat (lima) faktor yang sangat mempengarui penegakan hukum, kelima faktor tersebut saling berkaitan erat, sehingga merupakan esensi dari penegkan hukum dan merupakan tolak ukur dari efektivitas penegakan hukum. Kelima faktor tersebut, adalah ${ }^{46}$ :

1. Faktor hukum sendiri, terutama undang-undang.

40 Ibid. HIm. 3

41 Satjipto Raharjo dalam Ibid. HIm. 5

42 Harsja W. Bactiar. IImu Kepolisian, Suatu Cabang IImu Pengetahuan yang Baru. Grassindo:Jakarta 1994.

43 Lawrence Friedman. The Legal System A Social Science Perspective. Russel Sage Foundation:New York. 1975. HIm. 16

44 Sudikno Mertokusumo. 1993. Bab-bab Tentang Penemuan Hukum. PT. Citra Aditya bekerja sama dengan Konsorsium Ilmu-ilmu Hukum, Departemen Pendidikan dan Kebudayaan dan The Asia Fodation: Bandung. HIm.2

45 Satjipto Raharjo dan Anton Tabah. Polisi, Pelaku, dan Pemikir. Gramedia Pustaka Utama, Jakarta. 1993. HIm. 65

46 Soejono Soekanto. Beberapa Catatan Tentang Psikilogi Hukum. PT. Citra Aditya Bhakti : Bandung 1993. HIm. 5-6 
2. Faktor penegak hukum, yakni pihak-pihak yang membuat dan menerapkan hukum .

3. Faktor sarana atau fasilitas yang mendukung penegakan hukum.

4. Faktor masyarakat, yakni lingkungan di mana hukum tersebut berlaku atau di terapkan.

5. Faktor kebudayaan, yakni sebagai hasil karya cipta dan rasa di dasarkan pada karsa manusia di dalam pergaulan hidup.

Berdasarkan uraian di atas, jelas bahwa faktor-faktor yang dapat mempengaruhi pelaksanaan atau penegakan hukum cukup banyak dan bervariasi. Akan tetapi, keseluruhan faktor tersebut faktor manusia yang menjalankan penegakan hukum itu sangat dominan untuk menentukan apakah penegakan hukum (pelayan penegakan hukum) itu berhasil atau tidak.

\section{Peradilan Pidana}

Penyelenggaraan peradilan pidana merupakan mekanisme bekerjanya aparat penegak hukum pidana mulai dari proses penyelidikan dan penyidikan, penangkapan, penahanan penuntutan, sampai pemeriksaan di sidang pengadilan atau dengan kata lain bekerjanya polisi, jaksa, hakim dan petugas lembaga pemasyarakatan demi mencapai tujuan peradilan pidana. ${ }^{47}$ Peradilan pidana merupakan suatu sistem karena dalam peradilan pidana terdapat beberapa lembaga yang masing-masing mempunyai wewenang dan tugas sesuai dengan bidangnya dan sesuai peraturan yang berlaku. Dalam peradilan pidana terdapat beberapa komponen namun sasaran semua lembaga adalah menanggulangi kejahatan dan mencegah kejahatan. ${ }^{48}$

Dalam masyarakat terdapat sejumlah sistem dan subsistem yang dapat mempengaruhi kehidupan manusia, salah satunya adalah sistem peradilan pidana. Terkait dengan hal ini, J.W. La Patra mengemukakan : 49

Many different societal sytems have an impactan an individual before he has contact with the criminal justice system. $H$ is bron witn ertain mental is physical abilitess and particular tendencies that may inherited. In the course of his life he comes in contact with may inherited. In the course of his life he comes in contact with various group, such as the family. Which important roles ion his life other societal system scononic, eduatinal, tehcnolical play and political among others have a substansial influence on his life.

Patra dalam kutipan di atas mengemukakan bahwa banyak sistem yang berbeda dalam bermasyarakat, yang mempunyai dampak pada perorangan sebelum ia mempunyai hubungan dengan peradilan pidana. la adalah pembawaan mental sejak lahir yaitu fisik, kemampuan dan kecenderungan untuk dapat menerima warisan. Selama hidupnya ia datang dalam hubungan dengan berbagai kelompok seperti keluarga. Peran penting dalam hidup masyarakat antara sistem ekonomi, teknologi, politik dan hubungan antara orang yang mempunyai suatu substansi yang mempengarui dalam hidupnya.

Administrasi peradilan pidana yang dilaksanakan oleh para penegak hukum berlangsung berdasarkan kaidah-kaidah hukum acara pidana. Beberapa karangan mengenai hukum acara pidana yang ditulis ahli hukum acara pidana di Belanda mengemukakan bahwa hukum acara mengatur : 50

a) Diutusnya kebenaran atas adanya persangkaan dilanggarnya undang-undang pidana. Pengusutan dilakukan oleh alat negara yang khusus diadakan untuk keperluan tersebut;

b) Diusahakan untuk mengusut para pelaku tindak pidana atau perbuatan yang melanggar undang-undang pidana itu;

c) Diikhawatirkan segala daya upaya agar pelaku perbuatan ditangkap jika perlu ditahan;

d) Alat bukti yang diperoleh dan berkumpul dari pengusutan dari kebenaran persangkutan melalui proses penuntutan diserahkan kepada hakim agar tersangka dapat dihadapkan kepada hakim;

e) Penyerahan kepada hakim adalah untuk diambil keputusan tentang terbukti tidaknya perbuatan yang disangkakan;

f) Menentukan upaya hukum yang dapat diperlukan terhadap putusan yang diambil hakim;

\footnotetext{
47 Yemil Anwar dan Adang. Sistem Peradilan Pidana. Widya Pajajaran: Bandung. 2009. HIm.28

48 Ibid.

49 J.W. La Patra dalam ibid. HIm. 2

50 Moeljanto. Asas-Asas Hukum Pidana. Rineka Cipta:Jakarta. 1993. HIm. 1
} 
g) Putusan yang pada akhirnya diambil berupa pidana atau tindak untuk dilaksanakan.

Salah satu landasan dalam penyelenggaraan peradilan pidana adalah Kitab Undang-Undang Hukum Acara Pidana (KUHAP). KUHAP mengatur cara-cara bagaimana negara menggunakan haknya untuk melakukan penghukuman dalam perkara-perkara yang terjadi. Hukum Acara Pidana merupakan suatu sistem kaidah norma yang diberlakukan negara dalam hal ini kekuasaan kehakiman untuk melaksanakan hukum pidana. Jadi fungsi hukum acara pidana untuk memberikan penetapan hukum terhadap seseorang tentang dipersalahkan atau tidak dan tentang penjatuhan pidana tertentu kepadanya. ${ }^{51}$

Wirjono Pradjodikoro, mengemukakan bahwa hukum acara pidana adalah acarabagaimana suatu badan hukum menuntut seseorang, cara mengambil suatu putusan dan cara melaksanakan suatu putusan pengadilan dan menjalankan suatu hukum pidana. ${ }^{52}$

Osman Simanjuntak, mengemukakan bahwa acara pidana secara umum dapat dikatakan sebagai himpunan ketentuan yang mengatur bagaimana melaksanakan hukum pidana material guna menjamin ketertiban dan ketentraman masyarakat guna mewujudakan keadilan dan kebenaran. ${ }^{53}$

Proses peradilan pidana mengenal beberapa asas hukum acara pidana yaitu : $: 54$

a) Perlakuan sama atas diri setiap orang di muka hukum dengan tidak tidak mengadakan pembedaan perlakukan;

b) Penangkapan, penahanan, penggeledahan dan penyitaan hanya dapat dilakukan berdasarkan perintah tertulis oleh pejabat yang diberikan kewenangan oleh undang-undang dan hanya dalam hal dengan cara yang diatur oleh undang-undang;

c) Setiap orang yang disangkah, ditangkap, ditahan, dituntut dan atau diharapkan di muka sidang wajib dianggap tidak bersalah sampai adanya putusan pengadilan yang menyatakan kesalahannya dan memperoleh kekuatan hukum yang tetap.

d) Kepada seseorang yang ditangkap, ditahan, dituntut ataupun diadili tanpa alasan berdasarkan undang-undang dan atau karena kekeliruan mengenai orangnya atau hukumnya wajib diberi ganti rugi dan rehabilitasi sejak tingkat penyelidikan dan para pejabat penegak hukum yang dengan sengaja atau karena kelalaiannya menyebabkan asas hukum tersebut dilanggar, dituntut, dipidana dan atau dikenakan hukuman administrasi.

e) Peradilan yang harus dilakukan dengan cepat, sederhana dan biaya ringan serta bebas, jujur dan tidak memihak harus diterapkan secara konsekuen dalam seluruh tingkat peradilan.

f) Setiap orang yang tersangkut perkara wajib diberikan kesempatan memperoleh bantuan hukum yang semata-mata diberikan untuk mekasanakan kepentingan pembelaan atas dirinya.

g) Kepada seorang tersangka, sejak saat dilakukan penangkapan dan atau penahanan selain wajib diberikan dakwaan dan dasar hukumnya, juga wajib diberitahukan hak untuk menghubungi dan minta bantuan penasihat hukum.

h) Pengandilan memeriksa perkara pidana dengan hadirnya terdakwa.

i) Sidang pemeriksaan pengadilan adalah terbuka untuk umum kecuali untuk hal yang diatur dengan undang-undang.

j) Pegawasan pelaksanaan putusan pengadilan dalam perkara pidana dilakukan oleh Ketua Pengdilan Negeri yang bersangkutan.

Aparat penegak hukum dalam melaksanakan tugasnya harus melihat dan melaksanakan rumusan KUHAP sebagai satu kesatuan integral dengan seluruh motivasi KUHAP mulai dari landasan filosofis, landasan konstitional dan UU Kekuasaan Kehakiman serta landasan tujuan yang digariskan dalam bagian konsiderans KUHAP. Landasan filosofi KUHAP dapat dilihat dalam huruf a konsiderannya yaitu Pancasila terutama sila pertama dan sila kedua. Jika mengacu pada nilai-nilai pancasila maka KUHAP mengakui bahwa setiap pejabat aparat penegak hukum maupun tersangka/terdakwa adalah: ${ }^{55}$

\footnotetext{
${ }^{51}$ Djoko Prakoso. Alat Bukti dan Kekuatan Pembuktian dalam Proses Pidana. Liberty: Yogyakarta.1988. HIm.1

52 Wirjono Pradjodikoro. Hukum Acara Pidana Di Indonesia. Sumur : Bandung. 1977. HIm. 43

53 Osman Simanjuntak. Teknik Penuntutan dan Upaya Hukum. Kejaksaan Agung RI. Jakarta.1994. HIm3.

54 Sudarto. Hukum dan Hukum Pidana. Alumni. Bandung, 1997. HIm. 36

${ }^{55}$ Muladi. Lembaga Pidana Bersyarat. P.T. Alumni: Bandung 2004, HIm. 11
} 
a) Manusia yang dependen kepada Tuhan. Semua manusia diciptakan oleh Tuhan dan kelahirannya ke permukaan bumi adalah karena kehendak Tuhan, oleh karena itu tidak boleh ada perbedaan asasi di antara sesama manusia, manusia sama-sama mengembangkan dan mempertahankan kodrat, harkat dan martabatnya sebagai manusia ciptaan Tuhan dan manusia memiliki hak kemanusiaan yang harus dilindungi tanpak kecuali.

b) Fungsi dan tugas apapun yang dilaksanakan oleh manusia hanya semata-mata dalam lingkup menunaikan amanat dari Tuhan yang maha esa.

c) Fungsi pengabdian pada kehendak Tuhan diwujudkan dengan menempatkan setiap manusia sebagai hamba Tuhan yang memiliki harkat martabat kemanusiaan yang harus dilindungi serta menghargai hak setiap manusia untuk mempertahankan kehormatan dan martabatnya.

Para penegak hukum harus mampu untuk berani dan menegakkan isyarat keadilan yang konsisten dengan konsep keadilan Tuhan untuk diwujudkan dalam penegakan hukum. Hal ini pulalah yang melandasi sehingga setiap putusan harus berkepala "Demi Keadilan Berdasarkan Ketuhahan yang Maha Esa" sebagaimana ditegaskan dalam Pasal 197 ayat (1) KUHAP. Oleh karena itu, suatu keadilan harus memiliki dimensi pertanggung jawaban kepada hukum, kepada diri sendiri, kepada masyarakat, dan kepada Tuhan yang Maha Esa.

Cita penegakan hukum acara pidana juga menitik beratkan pada cita kemanusiaan sehingga setiap manusia apakah tersangka atau terdakwa maupun saksi harus diperlakukan sebagai manusia yang mempunyai harkat martabat dan diperlukan secara manusiawi dan beradab. Dengan landasan kemanusiaan ini maka diharapkan terciptanya suatu penegakan hukum yang luhur dan berbudi yang menempatkan kedudukan aparat penegak hukum sebagai pengendali hukum demi mempertahankan perlindungan ketertiban masyarakat pada satu pihak dan menempatkan kedudukan tersangka/terdakwa sebagai subjek hukum yang berhak mempertahankan derajat dan mertabatnya. ${ }^{56}$

Kitab Undang-Undang Hukum Acara Pidana merupakan pembaharuan hukum acara pidana, yang memuat hak-hak yang sebelumnya tidak dikenal dalam HIR. Untuk mencapai tujuan pembinaan aparat hukum maka tujuan dari KUHAP dikemukakan sebagai berikut: ${ }^{57}$

a) Meningkatkan pembinaan ketertiban aparat penegak hukum sesuai dengan fungsi dan wewenang masing-masing;

b) Meningkatkan pembinanan profesionalisme;

c) Pembinaan dan peningkatan sikap mental;

d) Menegakkan hukum dan keadilan;

e) Melindungi harkat dan martabat manusia;

f) Menegakkan ketertiban dan kepastian hukum.

Proses peradilan pidana merupakan suatu proses penegakan hukum yang dilakukan secara bertanggung jawab untuk mengatur lahirnya putusan yang berintikan pada keadilan. Berkenaan dengan putusan pengadilan, Gustav Radurch, mengemukakan bahwa suatu putusan pengadilan ideal harus mengandung aspek keadilan, kepastian hukum, dan aspek kemanfaatan Ketiga ide hukum ini tidak mudah untuk diterapkan karena tidak menutup kemungkinan adanya ketidakserasian antara tuntuntan kepastian hukum di satu sisi dengan tuntutan keadilan masyarakat di sisi yang lain. Namun demikian sedapatnya ketiga aspek tersebut dapat diwujudkan secara proporsional dan jika terjadi benturan maka akan lebih bijak jika lembaga peradilan tetap mengedepankan dan menjunjung tinggi keadilan. ${ }^{58}$

Pidana dipandang sebagai suatu nestapa yang dikenakan kepada pembuat karena melakukan suatu delik. Ini bukan merupakan tujuan akhir tetapi tujuan terdekat. Inilah perbedaan antara pidana dan tindakan karena tindakan dapat berupa nestapa juga, tetapi bukan tujuan. Tujuan akhir pidana dan tindakan dapat menjadi satu, yaitu memperbaiki pembuat. ${ }^{59}$

\footnotetext{
56 Hermien Hadiati Koeswadji. Perkembangan Macam-Macam Pidana dalam Rangka Pembangunan Hukum Pidana. PT. Citra Aditya Bakti: Bandung 1995. HIm. 11-12

57 Surastini Fitriasih. Perlindungan Saksi dan Korban Sebagai Saranan Menuju Proses Peradilan (Pidana) Yang Jujur dan adil.Makala www. Pemantau Peradilan com.

58 Dalam Rusli Muhammad. Kemandirian Pengadilan Indonesia. FH UII Press : Yogyakarta. 2010.HIm.162

59 Barda Nawawi Arief. Perbandingan Hukum Pidana. Raja Grafindo Persada, Jakarta. 2002. HIm.4
} 
Muladi dan Barda Nawawi Arief, menyimpulkan bahwa pidana mengandung unsurunsur atau ciri-ciri sebagai berikut :

a) Pidana itu pada hakekatnya merupakan suatu pengenaan penderitaan atau nestapa atau akibat-akibat lain yang tidak menyenangkan;

b) Pidana itu diberikan dengan sengaja oleh orang atau badan yang mempunyai kekuasaan (oleh yang berwewenang);

c) Pidana itu dikenakan kepada seseorang yang telah melakukan tindak pidana menurut undang-undang. ${ }^{60}$

Sudarto, mengemukakan bahwa penghukuman berasal dari kata dasar hukum, sehingga dapat diartikan sebagai menetapkan hukum atau memutuskan tentang hukumanya (berschen) menetapkan hukum untuk suatu peristiwa itu tidak hanya menyangkut hukum pidana saja, akan tetapi juga hukum perdata. Oleh karena itu maka tulisan ini berkisar pada hukum pidana, maka istilah tersebut harus disempitkan artinya yaitu penghukuman dalam perkara pidana, yang kerap kali bersinonim dengan pemidanaan atau pemberian atau penjatuhan pidana oleh hakim. ${ }^{61}$

M. Sholehuddin, mengemukakan bahwa tujuan pemidanaan harus sesuai dengan politik hukum pidana dimana harus diarahkan kepada perlindungan masyarakat dari kesejahteraan serta keseimbangan dan keselarasan hidup dengan memperhatikan kepentingan masyarakat/negara, korban, dan pelaku. ${ }^{62}$

Sifat-sifat dari unsur pidana berdasarkan atas tujuan pemidanaan tersebut, yaitu :

a) Kemanusiaan, dalam arti bahwa pemidanaan tersebut menjunjung tinggi harkat martabat seseorang.

b) Edukatif, dalam artian bahwa pemidanaan itu mampu membuat orang sadar sepenuhnya atas perbuatan yang dilakukan dan menyebabkan ia mempunyai sikap jiwa yang positif dan konstruktif bagi usaha penanggulangan kejahatan.

c) Keadilan, dalam artian bahwa pemidanaan tersebut dirasakan adil (baik oleh terhukum maupun oleh korban ataupun masyarakat).

Muladi mengemukakan pula pandangannya bahwa tujuan pemidanaan haruslah bersifat integratif, yaitu : 63

a) Perlindungan masyarakat;

b) Memelihara solidaritas masyarakat;

c) Pencegahan (umum dan khusus);

d) Pengimbalan/pengimbangan.

\section{PEMBAHASAN}

Dalam penyelesaian perkara pidana, banyak ditemukan korban penganiayaan kurang memperoleh perlindungan hukum yang memadai, baik perlindungan yang sifatnya immaterial maupun material, korban adalah pihak yang sangat dirugikan dalam suatu tindak pidana yang seharusnya mendapat perlindungan, korban ditempatkan sebagai alat bukti yang memberikan keterangan yaitu hanya sebagai saksi, sehingga kemungkinan bagi korban penganiayaan untuk memperoleh keleluasaan dalam memperjuangkan haknya adalah kecil dan seharusnya mendapatkan perlindungan yang sama.

Hal ini sejalan dengan kenyataan yang diperoleh dari pengaturan perlindungan terhadap korban penganiayaan dalam Undang-Undang Perlindungan Saksi dan Korban di mana Undang-Undang ini pun lebih dominan menempatkan korban dalam kedudukannya sebagai saksi sehingga perlindungannya pun sebatas pada perlindungannya sebagai saksi korban bukan sebagai korban penganiayaan yang telah mendapat kerugian baik materi maupun immateri.

Dalam hal pengertian tentang penganiayaan tidak ditegaskan dalam Undang-Undang, namun menurut yurisprudenci penganiayaan ialah perbuatan dengan sengaja yang menibulkan rasa tidak

\footnotetext{
${ }^{60}$ Muladi dan Barda Nawawi Arief. Teori-teori dan Kebijakan Pidana. Alumni :Bandung.1992. HIm 158.

61 Sudarto. Hukum dan Hukum Pidana. Alumni. Bandung, HIm. 36

${ }^{62}$ Sholehuddin. M. Sistem Saksi dalam Hukum Pidana. PT. Raja Grafindo Persada. Jakarta. 2004.HIm.59

63 Muladi. Lembaga Pidana Bersyarat. Alumni : Bandung, HIm. 11
} 
enak, rasa sakit atau luka, dan menurut Pasal 531 ayat (4) KUHP, penganiayaan disamakan perbuatan dengan sengaja merusak kesehatan orang. Berikut ini adalah penggolongan tindak pidana penganiayaan.

Penganiayaan dapat di kategorikan dalam 3 gologan yaitu penganiayaan biasa, penganiayaan ringan, dan penganiayaan berat. Hal ini di tentukan dari akibat yang ditimbulkan dari tindak pidana tersebut.

Perlindungan hukum terhadap korban kejahatan yang disebutkan di atas idealnya diatur secara lebih detail dan tegas dalam peraturan perundang-undangan untuk memberikan pedoman bagi aparat penegak hukum dalam melaksanakan penegakan hukum dan menjadi dasar bagi keikutsertaan masyarakat dalam mendukung adanya perlindungan hukum terhadap korban penganiayaan. Hal ini antara lain dapat dilakukan dengan menempatkan korban sebagai pihak yang harus diberikan tempat yang istimewa dalam proses penegakan hukum.

Perundang-undangan yang saat ini berlaku (ius contitutum/ius operatum), perlindungan korban lebih banyak sebagai "perlindungan abstrak" atau perlindungan tidak langsung. Hal ini dikarenakan tindak pidana menurut perundang-undangan pidana tidak dilihat sebagai perbuatan yang menyerang/melanggar kepentingan hukum seorang (korban) secara pribadi dan konkrit, tetapi hanya bisa dilihat sebagai pelanggaran "tertib hukum in abstracto".

Hal ini menunjukkan bahwa sistem sanksi dan pertanggungjawaban pidananya tidak tertuju pada perlindungan korban secara langsung dan konkrit, tetapi hanya perlindungan korban secara tidak langsung dan abstrak. Jadi pertanggungjawaban pidana terhadap pelaku bukanlah pertanggungjawaban terhadap kerugian/penderitaan korban secara langsung dan konkret, tetapi lebih tertuju pada pertanggung jawaban yang bersifat pribadi/individu.

Upaya perlindungan terhadap korban dalam perkembangan internasional juga cendrung terhadap pidana ganti rugi antara lain dalam Sidang Umum PBB tanggal 15 Desember 1985 yang telah menerima resolusi tentang "Declaration of Basic Principles of Justice for Victims of Crime and Abuse of Power" No. 40/34, yang antara lain mengatur tentang restitusi dan kompensasi pada korban tindak pidana umum maupun khusus.

Dalam hal ini penulis melihat bahwa terdapat suatu realita yang tidak dapat dibantah bahwa kepentingan dan hak-hak pelaku penganiayaan dalam KUHP lebih diperlihatkan dan diutamakan dari kepentingan dan hak-hak Victim of Crime itu sendiri. Hal ini dapat dilihat dalam pengaturan KUHAP di mana sejak awal proses pemeriksaan hak-hak offender (pelaku) dilindungi, dengan pengaturan hak memperoleh bantuan hukum, memperoleh perlakuan yang baik, dijauhkan dari penyiksaan, diberitahukan penganiayaan yang disangkakan kepadanya, hak memperoleh pemidanaan secara manusiawi, bahkan hak untuk meminta ganti rugi manakala terjadi kekeliruan dalam proses perkara pidana, singkatnya segala hak dan atribut yang melekat pada offender sebagai manusia dikemas dalam KUHAP sedangkan hak victim of crime dikemas sangat minim, bahkan tidak diakomodir oleh KUHAP.

Selanjutnya penulis melihat bahwa baik dalam KUHP maupun dalam KUHAP sebagai induk pidana positif belum diatur secara tegas mengenai kedudukan korban penganiayaan di Indonesia, padahal aturan mengenai segala warga Negara bersamaan kedudukannya didalam hukum dan pemerintahan sebagaimana yang tertuang didalam Pasal 27 ayat (1) UUD 1945. Aturan mengenai kedudukan pelaku penganiayaan mendapatkan jaminan perlindungan hokum sebagaimana diatur dalam KUHAP namun bagi korban penganiayaan belum diatur, hal ini tidak mencerminkan adanya rasa keadilan bagi korban penganiayaan.

Uraian diatas menunjukkan bahwa dalam penyelesaian perkara pidana, seringkali hukum terlalu mengedepankan hak-hak tersangka/terdakwa, sementara hak-hak korban diabaikan. Dalam membahas hukum acara pidana khususnya yang berkaitan dengan hak-hak asasi manusia, ada kecendrungan untuk mengupas hal-hal yang berkaitan dengan hak-hak tersangka tanpa memperhatikan pula hak-hak para korban.

Berikut adalah uraian mengenai pengaturan perlindungan korban penganiayaan dalam beberapa peraturan perundang-undangan di Indonesia :

\section{a. Kitab Undang-Undang Hukum Acara Pidana (KUHAP)}

Kitab Undang-Undang Hukum Acara Pidana (KUHAP) yang dibetuk berdasarkan UndangUndang No. 8 Tahun 1988 wajib didasarkan pada falsafah/pandangan di dalam ketentuan materi pasal atau ayat tercermin perlindungan terhadap hak asasi manusia. Aturan dalam KUHAP inilah yang merupakan payung dari seluruh hukum acara pidana yang mengatur mengenai saksi dan hak- 
haknya. Pengertian dan defenisi saksi dapat dilihat dalam pasal 1 angka 36 Kitab Undang-Undang Hukum Acara Pidana. Saksi adalah orang yang dapat memberikan keterangan guna kepentingan penyidikan, penuntutan, dan peradilan tentang suatu perkara pidana yang ia dengar sendiri, ia lihat sendiri, dan ia alami sendiri.

Dalam Kitab Undang-Undang Hukum Acara Pidana, diatur beberapa hak yang dapat digunakan oleh korban penganiayaan dalam suatu proses peradilan pidana, yakni sebagai berikut :

1. Hak untuk melakukan control terhadap penyidik dan penuntut umum;

Hak ini adalah hak untuk mengajukan dan/atau penuntutan dalam kapasitasnya sebagai pihak ketiga yang berkepentingan (Pasal 77 no. 80 KUHAP). Hal ini penting untuk diberikan guna menghindari adanya upaya dari pihak-pihak tertentu dengan berbagai motif yang bermaksud menghentikan proses pemeriksaan.

2. Hak korban berkaitan dengan kedudukannya sebagai saksi

Hak ini adalah hak untuk mengundurkan diri sebagai saksi (Pasal 168 KUHAP). Kesaksian (saksi) korban sangat penting untuk diperoleh dalam rangka mencapai suatu kebenaran materiil. Oleh karena itu, untuk mencegah korban mengundurkan diri sebagai saksi, diperlukan sikap proaktif dari aparat penegak hukum untuk memberikan jaminan keamanan bagi korban dan keluarganya saat mengajukan diri sebagai saksi.

3. Hak untuk menuntut ganti rugi akibat suatu tindak pidana yang menimpa diri korban melalui cara penggabungan perkara perdata dengan perkara pidana (Pasal 98 sampai Pasal 101).

Hak ini diberikan guna memudahkan korban untuk menuntut ganti rugi pada tersangka/terdakwa. Permintaan penggabungan perkara gugatan ganti rugi hanya dapat diajukan selambat-lambatnya sebelum penuntut umum mengajukan tuntutan pidana, atau jika penuntut umum tidak hadir, permintaan tersebut diajukan selambat-lambatnya sebelum hakim menjatuhkan putusan. Penggabungan gugatan ganti rugi dapat diajukan apabila pihak yang dirugikan mengajukan penggabungan ganti rugi terhadap si terdakwa dalam kasus yang didakwakan kepadanya. Penggabungan gugatan ganti rugi dilaksanakan berdasarkan hukum acara pidana pada tingkat banding.

4. Hak bagi keluarga korban untuk mengizinkan atau tidak mengizinkan polisi melakukan otopsi (Pasal 134-136 KUHAP).

Hak bagi keluarga korban untuk mengizinkan polisi melakukan otopsi (Pasal 134-136 KUHAP). Mengizinkan atau tidak mengizinkan polisi untuk melakukan otopsi juga merupakan suatu bentuk perlindungan korban kejahatan, mengingat masalah otopsi ini bagi beberapa kalangan sangat erat kaitannya dengan masalah agama, adat istiadat, serta aspek kesusilaan kesopanan lainnya.

Berkaitan dengan hak korban untuk mengajukan tuntutan ganti rugi melalui cara penggabungan perkara sebagaimana diatur dalam Pasal 98 sampai 101 KUHAP. Pihak-pihak yang berkepentingan perlu memperhatikan beberapa hal, yaitu sebagai berikut :

1. Kerugian yang terjadi harus ditimbulkan oleh tindak pidana itu sendiri.

2. Kerugian yang ditimbulkan oleh tindak pidana atau orang lain yang menderita kerugian (korban) sebagai akibat langsung dari tindak pidana tersebut

3. Gugatan ganti kerugian yang diakibatkan tindak pidana tadi ditujukan kepada sipelaku tindak pidana (terdakwa)

4. Dan, tuntutan ganti rugi yang diajukan kepada terdakwa tadi digabungkan atau diperiksa dan diputus sekaligus bersamaan pada pemeriksaan dan putusan perkara pidana yang didakwakan kepada terdakwa dan dalam bentuk satu putusan.

Sejalan dengan itu ganti rugi adalah hak seorang untuk mendapat pemenuhan atas tuntutannya yang berupa imbalan sejumlah uang karena ditangkap, ditahan, dituntut ataupun diadili tanpa alasan yang berdasarkan undang-undang atau karena kekeliruan mengenai orangnya atau hukum yang diterapkan menurut cara yang diatur dalam undang-undang ini (pasal 1 butir ke-22 KUHAP). Selanjutnya dalam Pasal 1 butir ke-23 KUHAP ditegaskan defenisi rehabilitasi sebagai hak seseorang untuk mendapat pemulihan haknya dalam kemampuan, kedudukan dan harkat serta martabatnya yang diberikan pada tingkat penyidikan, penuntutan atau peradilan karena ditangkap, ditahan, dituntut ataupun diadili tanpa alasan yang berdasarkan undang-undang atau hukum yang diterapkan menurut cara yang diatur dalam undang-undang atau hukum yang diterapkan menurut cara yang diatur dalam undang-undang ini.

Pasal 98 ayat (1) KUHAP menegaskan bahwa : 
"Jika suatu perbuatan yang menjadi dasar dakwaan di dalam suatu pemeriksaan perkara pidana oleh pengadilan negeri menimbulkan kerugian bagi orang lain, maka hakim ketua sidang atas permintaan orang itu dapat menetapkan untuk menggabungkan perkara gugatan ganti kerugian kepada perkara pidana itu".

Ganti kerugian yang dimaksud pada gabungan perkara gugatan ganti kerugian, bukan tuntutan ganti kerugian akibat penangkapan, penahanan, penuntutan atau peradilan yang tidak berdasar undang-undang. Akan tetapi merupakan tuntutan ganti kerugian yang ditimbulkan tindak pidana itu sendiri, tuntutan ganti kerugian yang diakibatkan tindak pidana kepada si pelaku tindak pidana yaitu terdakwa. Dan tuntutan ganti rugi yang diajukan kepada terdakwa digabung dan diperiksa serta diputus sekaligus bersamaan dengan pemeriksaan dan putusan perkara pidana yang didakwakan kepada terdakwa.

Ketentuan dalam KUHAP menempatkan korban dalam kapasitas sebagai saksi dan korban sehingga seorang korban dari suatu tindak pidana yang juga melakukan kesaksian ia berhak meminta ganti kerugian. Ganti kerugian itu hanya dapat diminta apabila saksi yang sekaligus menjadi korban itu menggabungkan gugatan ganti kerugian kepada perkara pidana yang bersangkutan. Ketentuan dalam KUHAP menurut peneliti menempatkan saksi hanya dalam kedudukan sebagai saksi sehingga ganti kerugian yang dapat diminta adalah dalam kedudukannya sebagai saksi. Hal tersebut tidak dapat diperlakukan mengingat adanya kendala-kendala yang dihadapi dalam proses peradilan pidana karena ada saksi yang lemah baik dari segi penjaminan akan hak memperoleh kemanan dirinya maupun hak mengemukakan kesaksiannya.

\section{b. Undang - Undang Nomor 13 Tahun 2006 Tentang Perlindungan Saksi dan Korban}

Pasal 1 angka 2 Undang-Undang Nomor 13 Tahun 2006 tentang perlindungan Saksi dan Korban disebutkan bahwa korban adalah seseorang yang mengalami penderitaan fisik, mental, dan/atau kerugian ekonomi yang diakibatkan oleh suatu tindakan pidana. Ketentuan Pasal 5 Undang-Undang ini menentukan adanya korban mempunyai hak serupa :

a. Memperoleh perlindungan atas keamanan pribadi, keluarga, dan harta benda, serta bebas dari ancaman yang berkenaan dengan kesaksian yang akan, sedang, atau telah diberikan;

b. Ikut serta dalam proses memilih dan menentukan bentuk perlindungan dan dukungan keamanan;

c. Memberikan tekanan tanpa tekanan;

d. Mendapat penerjemah;

e. Bebas dari pertanyaan yang menyerat;

f. Mendapatkan informasi mengenai perkembangan khusus;

g. Mendapat informasi mengenai putusan pengadilan;

h. Mengetahui dalam hal terpidana dibebaskan;

i. Mendapat identitas baru;

j. Mendapat tempat kediaman baru;

k. Memperoleh bantuan biaya transfortasi sesuai dengan kebutuhan;

I. Mendapat nasihat hukum; dan/atau

m. Memperoleh bantuan biaya hidup sementara sampai batas waktu perlindungan berakhir.

n. Dalam hal terhadap korban pelanggaran hak asasi manusia (HAM) yang berat selain hal di atas, juga berhak pula untuk mendapatkan bantuan medis dan bantuan rehabilitasi psiko-sosial.

Pengaturan perlindungan korban dalam UU No. 13 Tahun 2006 menunjukkan bahwa pembentuk undang-undanag ingin mengajukan polarisasi pemikiran dengan titik tolak tujuan hukum pidana sebagai sarana untuk perlindungan masyarakat (social defence) dalam arti melindungi masyarakat terhadap penganiayaan dengan memperbaiki atau memulihkan kembali (rehabilitasi) kepada si pelaku tanpa mengurangi kesimbangan kepentingan perorangan dalam masyarakat.

Dalam ketentuan umum Pasal 1 butir (1) saksi adalah orang yang memberikan keterangan guna kepentingan penyelidikan, penyidikan, penuntutan, dan pemeriksaan di sidang pengadilan tentang suatu perkara pidana yang ia dengar sendiri, ia lihat sendiri, dan/atu ia alami sendiri. UU perlindungan saksi dan korban ini masih tetap menggunakan konsep tentang pengertian saksi seperti yang diatur oleh KUHAP. Perbedaan dengan rumusan KUHAP adalah bahwa status saksi dalam UU ini memang lebih maju, karena berupaya mencoba memasukkan atau (memperluas) 
perlindungan terhadap orang-orang yang membantu dalam upaya penyidikan pidana yang berstatus pelapor atau pengadu.

Namun perlindungan terhadap status saksi dalam konteks penyelidikan ini pun masih terbatas dan kurang memadai karena terbentur pada doktrin yang diintrodusir KUHAP, dimana saksinya harulah orang yang berketerangan perkara pidana yang ia lihat sendiri, dengar sindir, dan ia alami sendiri. Penggunaan doktrin inilah yang kemudian akan membantasi perlindungan terhadap saksi yang berstatus pelapor atau pengadu. Karena dalam banyak kasus ada orang yang berstatus pelapor ini kadangkalah bukanlah orang yang mendengar, melihat atau mengalami sendiri perkara tersebut.

Selain itu dalam konteks "defenisi saksi" yang terbatas tersebut, UU ini juga (tidak ada ditemukan/diatur) melupakan orang yang memberikan bantuan kepada aparat penegak hukum untuk keterangan dan membantu proses pemeriksaan pidana yang status ahli (orang yang memiliki keahlian khusus). Tidak dicantumkannya secara jelas sebagaimana yang disebutkan diatas akan menimbulkan masalah dan membebani lembaga perlindungan saksi dan korban dalam pelaksanaanya.

\section{c. Peraturan Pemerintah Nomor 3 Tahun 2002}

Landasan hukum dari pengadilan HAM adalah Undang-Undang No. 26 Tahun 2000 tentang pengadilan HAM namun hukum acara di dalam pengadilan HAM tetap menggunakan mekanisme acaranya tetap sama dengan kedudukan korban dalam KUHAP.

Peraturam Pemerintah Nomor 2 Tahun 2002 tentang tata cara perlindungan terhadap korban dan saksi dalam pelanggaran HAM berat memberikan perlindungan sejak tahap penyelidikan, penyidikan, penuntutan sampai pemeriksaan disidang pengadilan. Perlindungan yang dimaksud di dalam peraturan pemerintah ini meliputi perlindungan fisik dan mental. Korban dan saksi tidak kenal biaya apapun atas perlindungan yang diberikan kepadanya. Perlindungan yang menonjol dari Peraturan Pemerintah ini adalah perlindungan tentang adanya perahasiaan identitas korban atau saksi dan adanya mekanisme pemberian keterangan pada saat siding di pengadilan tanpa bertatap muka dengan tersangka,

Peraturan pemerintah Nomor 2 Tahun 2002 secara khusus memberikan perhatian kepada korban pelanggaran HAM berat saja, dan seharusnya juga diberikan kepada korban penganiayaan yang diatur dalam pidana umum (KUHAP), Korban diberikan konpensasi, restitusi dan rehabilitasi untuk selanjutnya mekanisme pemberian kompensasi, restitusi dan rehabilitasi terhadap korban pelanggaran HAM berat diatur dalam Peraturan Pemerintah Nomor 3 Tahun 2002 . Oleh karena itu, dapat dikatakan bahwa Peraturan Pemerintah Nomor 2 Tahun 2002, yang mengatur mengenai perlindungan saksi dan korban merupakan produk hukum yang tidak dapat digunakan secara maksimal. Hal ini disebabkan kedudukan Peraturan Pemerintah yang berada dibawah UndangUndang, sehingga secara yuridis Peraturan Pemerintah tidak dapat digunakan untuk pemenuhan hak-hak saksi dan korban ketika berhadapan dengan Undang-Undang, dalam hal ini KUHAP yang mengatur hal yang berbeda dengan Peraturan Pemerintah tersebut.

\section{d. Peraturan Pemerintah Nomor 44 Tahun 2008}

Peraturan Pemerintah Nomor 44 Tahun 2008 Tentang Pemberian Kompensasi, Restitusi dan Bantuan menurut ketentuan Pasal 8 Undang-Undang Perlindungan saksi dan korban menentukan bahwa perlindungan saksi dan korban diberikan sejak tindak penyidikan dimulai dan berakhir sesuai dengan ketentuan sebagaimana didalam Undang-Undang. pada :

Gambaran tentang dasar alasan Negara memberikan kompensasi pada prinsipnya bertolak

1. Kewajiban Negara melindungi warga negaranya;

2. Kemungkinan ketidak mampuan pelaku tindak podana memberikan ganti rugi yang cukup;

3. Sosiologi hukum berpandangan bahwa tindak yang timbul adalah andil kesalahan masyarakat atau tindak pidana sebagai anak kandung masyarakat yang diakibatkan tindak pidana.

Sedangkan pemberian kompensasi, Restitusi dan dan bantuan kepada korban yang sealjutnya disebut Peraturan Pemerintah Pemberian Kompensasi, Restitusi, dan Bantuan kepada Korban menentukan : 
Pasal 2 ayat (1)

Pasal 20 ayat (1)

Pasal 34 ayat (1)

Pasal 34 ayat (2)
: Pelanggaran HAM yang berat berhak mendapatkan Kompensasi

Korban HAM yang berat berhak mendapat restitusi

Korban HAM berat memperoleh bantuan

Bantuan sebagaimana pada ayat (1) dapat berupa :

1. Bantuan medis

2. Bantuan rehabilitasi dan psiko-sosial

Korban kejahatan yang mendapatkan kompensasi, restitusi dan rehabilitasi menurut Undang-Undang Pengadilan HAM hanyalah korban kejahatan dalam keadaan tertentu saja, sedang korban kejahatan dalam keadaan biasa tidak mendapatkan kompensasi dan restitusi, termasuk korban penganiayaan.

Sehubungan dengan itu didalam Pasal 39 ayat (2) UU Nomor 5 Tahun 1997 tentang psikotropika disebutkan bahwa rehabilitasi sebagaimana dimaksud pada ayat (1) meliputi rehabilitasi medis dan rehabilitasi sosial. Rehabilitasi medis adalah suatu proses kegiatan pelayanan kesehatan secara utuh pengguna psikotropika yang menderita sindroma ketergantungan dapat mencapai kemamfaatan semaksimal mungkin sementara itu rehabilitasi social adalah proses kegiatan pemulihan dan pengembangan baik fisik, mental maupun social agar pengguna psikotropika yang menderita sindroma ketergantungan dapat melaksanakan fungsi secara social secara optimal dalam kehidupan bermasyarakat.

Yang kita ketahui selama ini program rehabilitasi terhadap korban hanya berfokus pada rehabilitasi medis sedangkan rehabilitasi sosial sering diabaikan, padahal rehabilitasi sosial memegang peranan yang sama pentingnya dengan rehabilitasi medis, berhasil mengatasi kecanduan seseorang terhadap psikotripika jika tidak diikuti dengan rehabilitasi social, orang tersebut akan dengan mudah kembali kelingkungan lamanya, kemudian akan kembali menjadi pecandu obat-obat terlarang.

Demikian pula yang termaktub didalam Undang-Undang Nomor 21 Tahun 2007 tentang pemenuhan hak-hak korban perdagangan orang pada poin c disebutkan bahwa hak untuk memperoleh rehabilitasi kesehatan, rehabilitasi social, pemulangan dan reintegrasi dari pemerintah apabila yang bersangkutan mengalami penderitaan fisik maupun psikis akibat perdagangan orang (Pasal 51).

Mencermati ketentuan-ketentuan yang mengatur mengenai perlindungan korban kejahatan maka dapat dikatakan bahwa perlindungan korban kejahatan dalam system hokum nasional belum memperoleh perhatian serius meskipun telah ada Undang-Undang yang mengatur secara tegas perlindungan korban. Beberapa peraturan perundang-undangan hanya mengatur secara sumir dan abstrak. Hal ini terlihat dari masih sedikitnya hak-hak korban kejahatan atau penganiayaan memperoleh pengaturan dalam perundang-undangan nasional serta ketidak seimbangan antara perlindungan korban kejahatan dengan pelaku kejahatan.

dikedepankan dan pihak terkait harus proaktif menyampaikan secara langsung kepada korban atau kepada masyarakat sehingga setiap ada korban penganiayaan yang terjadi di Kota Tidore Kepulauan dengan sendiri akan melakukan upaya hukum atau menuntut haknya, baik kepada pihak kepolisian, kejaksaan maupun kepada pihak pengadilan.

\section{KESIMPULAN}

- Pengaturan perlindungan hukum terhadap korban tindak pidana penganiayaan diatur dalam perundang-undangan namun kurang optimal. Terutama berkaitan dengan kerugian terhadap korban. Hal ini karena peraturan perundang-undangan mengatur secara sumir dan abstrak. Tidak secara tegas dan spesifik menempatkan korban penganiayaan sebagai bagian dari sistem peradilan pidana.

\section{E. SARAN}

- Untuk perlindungan hak-hak korban tindak pidana dimasa yang akan datang perlu langkah-langkah antara lain dalam hukum acara pidana nasional memuat ketentuan yang jelas, tegas dan berimbang 
mengenai perlindungan terhadap hak-hak korban, korban penganiayaan agar kedudukan korban setara dengan kedudukan pelaku tindak pidana

\section{DAFTAR PUSTAKA}

Ahmad Kamil. 2012. Mediasi Penal dalam Penanganan Tindak Pidana. Mahkamah Agung Republik Indonesia : Jakarta.

Anshari Dimayanti. 2013. Kebijakan Perlindungan Hukum Terhadap Saksi dan korban. Universitas Diponegoro : Semarang.

Ansori. 2011. Perlindungan Hukum Terhadap Korban Perkosaan Dalam Peradilan Pidana di Indonesia. Disertasi : Universitas Brawijaya : Malang.

Barda Nawawi Arief. 2002. Perbadingan Hukum Pidana. PT. Raja Grafinbo Persada : Jakarta. 2001. Masalah Penegakan Hukum Dan Kebijakan Hukum Pidana dalam Penanggulangan Kejahatan. PT. Citara Aditya Bakti : Bandung.

Bedi Setiawan Al Fahmi. 2002. Perlindungan Korban Tindak Pidana Perkosaan Dalam Proses peradilan Pidana Perspektif Pembeharuan Hukum Acara Pidana Indonesia. Jurnal Hukum dan Pembangunan No. 1 Vol. 16 Januari 2009. Badan Penerbit FH UI : Depok

Brian Z. Tamanaha. 2001. The Rule of Law Theory. Oxfory University : New York

Lies Sulistiani. 2010. Perlindungan Saksi dan Korban di Indonesia. Press Release No.02/LPSK/PR/II/2010. Lembaga Perlindungan Saksi Republik Indonesia : Jakarta.

Lili Rasjidi dan B Arief Sidharta. 1994. Filsafat Hukum Madzab dan Refleksi. Remaja Rosda Karya : Bandung.

Mardjono Reksodiputro. 2007. Kriminologi dan Sistem Peradilan Pidana (Kumpulan Karangan, Buku Kedua), Pusat Pelayanan Keadilan dan Pengabdian Hukum (d/h Lembaga Kriminologi) Universitas Indonesia : Jakarta.

Mochtar Kusumaatmadja. 2003. Pengatar Hukum Indonesia. Pusat Studi Wawasan Nusantara, Hukum dan Pembagunan bekerjasama dengan Penerbit P.T. Alumni : Bandung.

Moeljatno. 1993. Asas-asas Hukum Pidana. Rineka Cipta : Jakarta

Muchsin. 2003. Perlindungan dan Kepastian Hukum bagi Investor di Indonesia. Magister Ilmu Hukum Program Pascasarjana Universitas Sebelas Maret : Surakarta.

Muhadar dkk. 2010. Perlindungan Saksi dan Korban dalam Sistem Peradilan Pidana. Putera Media Nusantara : Surabaya.

Muladi. 2004. Lembaga Pidana. Bersyarat. Alumni : Bandung.

Muladi dan Arief dan Barda Nawawi Arief. 1992. Teori-teori dan Kebijakan Pidana. Alumni : Bandung.

Philipus M. Hadjon 1987. Perlindungan hukum Bagi Rakyat di Indonesia; Sebuah Studi Tentang Prinsiprinsip, Penerapannya oleh Pengadilan Dalam Lingkungan Peradilan Umum dan Pembentukan Peradilan Administrasi Negara. Bina IImu : Surabaya.

Poerwadarminta.1998. Kamus bahasa Indonesia. Balai Pustaka : Jakarta.

Prabowo dan Dwi Riyanti. 1998. Masalah Kejiwaan Berbagai Profesi. Sinar Grafika, Jakarta

Rena Yulia. 2011. Viktimologi: Perlindungan Hukum Terhadap Korban Kejahatan. Jurnal Intelek Vulome 7 tanggal 3 Desember 2011.

Roeslan Saleh. 1984. Segi Lain Hukum Pidana. Ghalia Indonesia : Jakarta.

Soejono Soekanto. 2007. Sosiologi suatu Pengantar. PT. Raja Grafindo Persada, Jakarta

Satjipto Rahardjo. 2009. Penegakan Hukum Suatu Tinjauan Sosiologi. Genta Publishing : Jakarta.

Setiono. 2004. Rule of law (Supremasi Hukum). Magister IImu Hukum Program Pascasarjana Universitas Sebelas Maret : Surakarta.

Sholehuddin, M. 2004. Sistem Sanksi dalam Hukum Pidana. PT.Raja Grafindo Persada: Jakarta.

Sudarto. 1997. Hukum dan Hukum Pidana. Alumni. Bandung.

Sudikno. Mertokusumo. 1999. Mengenal Hukum, Suatu Pengantar. Liberty : Yogyakarta.

Wirjono Prodjodikoro. 1977. Hukum Acara Pidana di Indonesia. Sumur : Bandung

Yesmil Anwar dan Adang. 2009. Sistem Peradilan pidana Widya Pajajaran : Bandung.

Undang - Undang Dasar Negara Republik Indonesia

Undang - Undang Nomor 13 Tahun 2006 Tentang Perlindungan Saksi dan Korban

Kitab Undang - Undang Hukum Acara Pidana

www.Grafiti. Com. 10 Februari 2015 
